\title{
Restitutionary Recovery for Rescuers of Human Life
}

One can accept the promotion of mutual aid as a valid ideal and urge our own courts to go further than they have in respecting it, but still contend that private law remedies are misdirected when apphied in this way to the saving of human life and health. The loss incurred, great though it be, is part of the price that human beings inust pay for their share in the human enterprise. ${ }^{1}$

-John P. Dawson ${ }^{2}$

There is no neutrality. If the law does not encourage rescue, it is sure to discourage it. If it does not compensate, it will indirectly penalize. If the rescuer who suffers injury or incurs expense or simply expends his skill goes without compensation, the law, so far as it influences conduct at all, is discouraging rescue. ${ }^{3}$

$$
\text { -Antony M. (Tony) Honoré }{ }^{4}
$$

The fundamental premise of the law of restitution is that "[a] person who has been unjustly enriched at the expense of another is required to make restitution to the other."5 Yet, despite this basic premise, the current operation of the law of restitution in situations involving the rescue of human life does not serve the purpose of preventing unjust enrichment. ${ }^{6}$

1. Dawson, Negotiorum Gestio: The Altruistic Intermeddler (pt. 2), 74 HARV. L. REv. 1073, 1127 (1961); see also Dawson, Negotiorum Gestio: The Altruistic Intermeddler (pt. 1), 74 HARV. L. REv. 817 (1961).

2. Late Charles Stebbins Fairchild Professor of Law, Harvard Law School, a prolific and influential author on the subject of restitution. Professor Dawson's writings imclude J. DAwSON \& G. Palmer, Cases on Restitution (2d ed. 1969); J. Dawson, UnJust EnRichment: A Comparative ANalysis (1951); Dawson, Restitution Without Enrichment, 61 B.U.L. REV. 563 (1981); Dawson, The Self-Serving Intermeddler, 87 HARV. L. REv. 1409 (1974); and Dawson, $A$ Symposium on Restitution-Foreword, 19 VAND. L. REV. 1019 (1966).

3. Honoré, Law, Morals, and Rescue, in THE Good SAMARITAN AND THE LAw 225, 232 (J. Ratcliffe ed. 1966).

4. Regius Professor of Civil Law, University of Oxford. Professor Honorés writings include

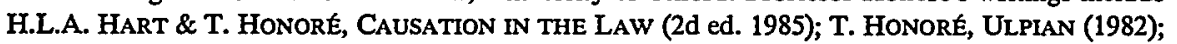
Honoré, The Background to Justinian's Codification, 48 TuL. L. REV. 859 (1974); Honoré, The Human Community and the Principle of Majority Rule, 8 SYDNEY L. REV. 599 (1979); and Honoré, Must We Obey? Necessity as a Ground of Obligation, 67 VA. L. REV. 39 (1981).

5. RESTATEMENT OF RESTITUTION $\$ 1$ (1937); see also RESTATEMENT (SECOND) OF REsTITUTION $\S 1$ (Tent. Draft No. 1, 1983) ("A person who receives a benefit by reason of an infringement of another person's interest, or of loss suffered by the otlier, owes restitution to lim in the manner and amount necessary to prevent unjust enrichment.").

6. See $1 \mathrm{G}$. Palmer, The LAw of Restitution $\$ 1.1$, at 2 (1978) (defining restitution as "liability based on unjust enriclıment"). Professor Palmer writes: "Unjust enricliment is an indefinable idea in the same way that justice is indefinable. But many of the meanings of justice are 
In the paradigm rescue situation, ${ }^{7}$ where the rescuee would have been killed or severely injured but for the rescuer's intervention, the rescuer has conferred a clear benefit on the rescuee, the rescuee's continued life and health. This benefit was conferred at the cost of the injuries suffered or expenses incurred by the rescuer. In this situation, the general principle of restitution should render the rescuee hable to his rescuer. ${ }^{8}$ It is unjust for the rescuee to enjoy the benefit of the rescuer's efforts while the rescuer alone bears the burden of costs. Nevertheless the general rule in the United States is that a nonneghigent rescuee has no legal liability to a nonprofessional rescuer.?

This Comment takes the position that the common law rule disallowing restitution for rescuers of hunian life is not only inconsistent with basic restitutionary principles, but contrary to considerations of inorality and social policy. The analysis will focus on the most difficult case: neither the rescuer, the rescuee, nor any third party is negligent; the rescue is successful; the rescuer is injured; and the rescuee does not freely offer to coinpensate the rescuer. In such a case, general common law principles of contract and restitution, as well as the societal values underlying those principles, support the recognition of a cause of action against the rescuee.

Part I of this Comment outlines the common law rules relating to a life rescue situation and the traditional rationales for such rules. Part I then analyzes several exceptions to the general rule of nonrecovery, and posits that the rationales underlying the exceptions also support the propositions advanced in this Comment. Part II develops the contrasting civil and inaritime law treatınent of rescue situations, both inore generous in allowing rescuer recovery than is the conunon law. Part III sets forth a proposal for reforn, whereby civil and niaritine law doctrines coinbine with traditional common law principles to grant a successful rescuer recovery against the rescuee for the rescuer's out-of-pocket expenses.

Under the proposed reforin, ${ }^{10}$ a nonprofessional rescuer who is injured in the course of a successful nonnegligent rescue of human life ${ }^{11}$ would recover out-of-pocket expenses froin the rescuee, including both

derived from a sense of injstice, and this is true of restitution since attention is centered on the prevention of injustice." Id. at 5 (footnote omitted).

7. For a case law example of the paradigmatic rescue situation, see infra text accompanying notes $134-40$.

8. For the sake of stylistic convenience, this Comment employs male pronouns to refer to all rescuers and recuees. Of course, rescuers and rescuees inight be female as well.

9. See 2 G. Palmer, supra note $6, \S 10.1$, at 358 .

10. The scope and rationale for this Comment's proposed reform are presented in greater detail infra in Part III, however, an understanding of its parameters is helpful for the contrasts to other systems presented infra in Parts I and II.

11. A rescuer of property should also be entitled to a recovery under some circumstances. See 
medical costs and lost earnings. The reform would not alter current law which allows professional rescuers (excluding those subject to a preexisting duty to undertake such rescues, such as policemen and firemen ${ }^{12}$ ) to recover normal fees whether or not the rescue is successful. The reform would grant expenses to an injured professional rescuer only if the rescuer could show that the rescuer's normal fees did not imclude a component to cover the risk of such injuries. In sum, a nonprofessional rescuer would recover only expenses, and only if the rescue were successful; a professional rescuer would recover only the usual fees, but regardless of whether or not the rescue was successful. In all cases, however, recovery would be subject to an equitable adjustment taking into account factors such as the rescuee's ability to pay and the competence with which the rescue was performed.

I

\section{COMMON LAW: THE RESCUER AS "INTERMEDDLER" OR "VOLUNTEER"}

Two fundamental common law values are autonomy and individualism. ${ }^{13}$ The most obvious legal manifestation of these values is the notion that an individual can mcur no private hability absent some volitional act indicating agreement (a contract) or causing harm (a tort). ${ }^{14}$ Lord Justice Bowen made the broadest and most often quoted judicial pronouncement on the subject:

The general principle is, beyond all question, that work and labour

infra note 28. The scope of this Comment and its proposed reform, however, do not include the property rescuer.

12. See infra note 33 .

13. A thoughtful overview of the tensions involved in the common law treatinent of voluntarisin is provided in Bickenbach, Unsolicited Benefits, 19 U.W. ONT. L. REV. 203, 203-05 (1981); see also Hope, Officiousness (pt. 1), 15 CoRNELL L.Q. 25, 29 (1929); Comment, Beyond Good Samaritans and Moral Monsters: An Individualistic Justification of the General Legal Duty to Rescue, 31 UCLA L. REV. 252, 255 (1983). Professor Hope's article, a seminal one in the area of restitutionary thought, ascribes an ethnological origin to the autonomy value:

Self-direction or personal autonomy is a inark of the English race. The Englishman, as opposed to one of Latin hineage, does not so easily coalesce with the mass. He distinctly wishes to live his own life, inake his own contacts, or as he frequently says, "muddle tlirougli" in his own way. He dislikes volunteered offerings-even of a conversational sort. Interference with his clioice or freedoin of movement is resented. This is familiar enough to travelers and students of English life and letters, and what is in English life will necessarily also exist in English law. ... It is an affair of national temperament.

Hope, supra, at 29 (footnote omitted). For a modern rejection of this notion, see S. STOLJAR, ThE LAIV OF QUASI-CONTRACT 161 n.4 (1964).

14. See generally Hope, supra note 13.

One modern commentator has written that our legal system has "split the whole field of civil obligation into contract obligations and tort obligations." Gilmore, Products Liability: $A$ Commentary, 38 U. CHI. L. REV. 103, 111 (1970). Contra 1 G. PALMER, supra note 6, § 1.1, at 2 ("There is another category that must be separated from [contract and tort]: this is liability based in unjust enrichment."). 
done or money expended by one man to preserve or benefit the property of anotlier do not according to English law create any lien upon the property saved or benefited, nor, even if standing alone, create any obligation to repay the expenditure. Liabilities are not to be forced on people behind their backs any more than you can confer a benefit upon a man against his will. ${ }^{15}$

American courts liave also viewed the possibility of incurring liability for unsolicited benefits as dangerous, ${ }^{16}$ uploolding the right of individuals to be free from externally imposed private liabilities.

Two interrelated mechanisms in the common law that operate to deny a rescuer a recovery are (1) a finding that the rescuer was an "officious intermeddler" 17 and (2) an irrebuttable presumption that an unofficious rescuer was a "mere volunteer" who intended to make a gift of lis services-in legal parlance, to "act gratuitously."18 The combined effect of these mechanisms, however, creates a "no-win" situation for a plaintiff rescuer seeking restitution. ${ }^{19}$

Two leading cases involving the rescue of property illustrate the

15. Falcke v. Scottish Imperial Ins. Co., 34 Ch. D. 234, 248 (Ch. App. 1886) (emphasis added). This statement has received apt criticism from commentators for being, among other things, overly broad and mapplicable to the case being decided. See, e.g., R. GOFF \& G. JONES, THE LAW OF REsTitution 263, 268-69, 278-79 (2d ed. 1978); Hope, supra note 13, at 26 \& n.4; McCamus, Necessitous Intervention: The Altruistic Intermeddler and the Law of Restitution, 11 OTTAWA L. REV. 297, 299-300 \& n.12 (1979); see also Hunter, Necessitous Intervention with Special Referencc to Preservation of Property, 23 U.N.B. L.J. 5, 6-7 (1974) (concluding that, regardless of the statement's faults, "the case has been followed in so many instances, both Englislı and Canadian, that it must be taken as the present statement of the law" (footnote omitted)).

16. See, e.g., Isle Royale Mining Co. v. Hertin, 37 Mich. 332, 338 (1877) (Cooley, C.J.) (If such recovery were allowed, "the only person reasonably secure against demands lie lias never assented to create, will be the person who, possessing nothing, is thereby protected against any thing being accidentally improved by another at his cost and to his ruin."); Force v. Haines, 17 N.J.L. 385, 387 (Sup. Ct. 1840) ("No man's private business, in the mode or time of it, would be under his control, or free from the interference of strangers, perhaps idlers, drunkards, and perhaps enemies, under such pretences, drawing him from business into litigation.").

17. See Wade, Restitution for Benefits Conferred Without Request, 19 VAND. L. REV. 1183, 1183-84 (1966); see also 2 G. PALMER, supra note 6, $\S 10.1$, at 359-60; RESTATEMENT OF RESTITUTION $\$ 2$ (1937) ("A person who officiously confers a benefit upon another is not entitled to restitution therefor.").

18. See 2 G. PALMER, supra note 6 , $\S 10.3$, at $369-70$; Wade, supra note 17 , at 1184, 1190-94; see also infra Part I, Section $C$.

19. Professor Hope clearly exposes the "no-win" situation created by the common law:

While emergency undoubtedly tends to absolve A's intervention from the fault of officiousness, it offers the courts their greatest opportunity to use the presumption of a gratuity. The result is that, precisely in those cases wliere B stands most in need of assistance, and where A's help will most certainly go unrebuked for officiousness, there $A$ if lie gives aid at all, must expect to give it for nothing.

Hope, supra note 13, at 38-39 (footnote omitted); see also Bickenbach, supra note 13, at 215 ("[The rescuer] will be deemed a 'voluntecr' unless lie can sliow lie intended to charge for his labours, but if in arguing this point he convinces the court that lie rescued the defendant, or his property, with the sole motive of creating an obligation on the defendant's part to pay him for his services, then the court may liold that lie was officious."). 
devastating effect on plaintiffs. In Bartholomew v. Jackson, ${ }^{20}$ plaintiff rescuer sought recovery for labor expended in protecting defendant's property. Plaintiff owned a wheat stubble field in which defendant had a stack of wheat. The plaintiff told the defendant that he planned to set fire to the stubble. Although the defendant promised to remove his wheat stack, he neglected to do so. With no time to seek defendant's consent, plaintiff reinoved the wheat of his own accord to prevent its destruction. In the one paragraph opinion fully reproduced below, the court reversed the trial court's judgment for plaintiff.

I should be very glad to affirm this judgment; for though the plaintiff was not legally entitled to sue for damages, yet to bring a certiorari on such a judgment was most unworthy. The plaintiff perforned the service without the privity or request of the defendant; and there was, in fact, no promise, express or implied. If a man humanely bestows his labour, and even risks his life, in voluntarily aiding to preserve his neighbour's house from destruction by fire, the law considers the service rendered as gratuitous, and it, therefore, forms no ground of action. The judgment inust be reversed. ${ }^{21}$

On similar facts, the plaintiff in Glenn v. Savage 22 alleged that during defendant's absence plaintiff had rescued some of defendant's lumber that had fallen imto the Columbia River. Plaintiff sought recovery for the reasonable value of his services. In reversing the trial verdict for plaintiff, the court declared:

The facts enumerated ... could not create a legal hability on the part of [defendant]. They may have been meritorious, and probably beneficial to [defendant], but this was not enough. To make him hable, he must either have requested the perfornance of the service, or, after he knew of the service, inust have promised to pay for it. The great and leading rule of law is, to deem an act done for the benefit of another without his request as a voluntary act of courtesy, for which no action can be sustained. The world abounds with acts of this kind done upon no request; but would more abound with ruinous hitigation, and the overthrow of personal rights and civil freedom, if the law was otherwise. ... The law will never pernit a friendly act, or such as was imtended to be an act of kindness or benevolence, to be afterwards converted into a pecuniary demand; it would be doing violence to some of the kindest and best effusions of the heart, to suffer them afterwards to be perverted by sordid avarice. Whatever differences inay arise afterward among men, let those meritorious and generous acts remain lasting monuments of the good offices intended in the days of good neighborhood and friendship; and let no after circumstances ever tanish or obliterate them from the recollection

20. 20 Johns 28 (N.Y. Sup. Ct. 1822).

21. Id. at 28-29 (emphasis in original).

22. 14 Or. 567,13 P. 442 (1887). 
of the parties. ${ }^{23}$

Although Bartholomew was decided in 1822, and Glenn in 1887, the leading modern American treatise on restitution notes that "there has been very httle change of attitude since then."24

The common law barriers to restitution, not just for rescue atteinpts but for all unsolicited benefits generally, are best understood as responses to three concerns: (1) the conferee may not have desired the benefit, and thus it would be unjust to hold him hable for it without his assent; ${ }^{25}(2)$ even if the benefit were desired, the conferee was unjustly enriched only to the extent of his subjective valuation of the benefit, and courts are not competent to determine the value of this sort of personal preference; ${ }^{26}$ and (3) if the conferor intended to bestow a gift, there is no unjust enrichment in allowing the conferee to retain the benefit. ${ }^{27}$

In the face of the common law hostility towards the claims of rescuers, each major theory of obligation-tort, contract, and restitutiondeveloped exceptions to the general rule of nonrecovery. These exceptions reflected an appreciation of the social value of rescue atteinpts, and served to mitigate the harshness of the general rule. This Comment will examme each exception and its supporting rationales. It will be seen that these policy rationales are not logically himited to the specific exception under discussion, but instead can be viewed as intermediate steps to the more liberal recovery rule suggested by this Comment.

\section{A. The Tort Exception: Danger Invites Rescue}

The most important practical exception to the rule of nonrecovery for life rescuers was accomplished by taking such clamis out of the problematic area of restitution altogether, and allowing recovery under an expansive construction of tort law. ${ }^{28}$ The paradigm case is Wagner $v$.

23. Id. at $577-78,13$ P. at 448 (citations omitted).

24. 2 G. PALMER, supra note $6, \S 10.3$, at 369 .

25. See supra notes $13 \& 15$ and accompanying text.

26. See Jones, Restitutionary Claims for Services Rendered, 93 LAW Q. REV. 273, 275 (1977); Wade, supra note 17 , at 1187 .

27. RESTATEMENT OF RESTITUTION $\S 1$ comment c (1937) ("The mere fact that a person benefits another is not of itself sufficient to require the other to make restitution therefor. Thus, one who improves his own land ordmarily benefits his neighbors to some extent, and one who makes a gift or voluntarily pays money which he knows he does not owe confers a benefit; in neither case is he entitled to restitution.").

28. The cases discussed earlier were property rescue cases, while the cases discussed in this section are life rescue cases. This Comment focuses on rescues involving threats to human life or health, not threats solely to property. Property rescues involving likely rescuer injury would be harder to justify as rcasonable, making it much more probable that such rescurers would be found negligent. Analagously, social policy would almost never support the encouragement of property rescue attempts where the probable result was rescuer injury. To the extent that property rescue cases meet the proposed reform's other criteria, many of the ideas underlying the reform would remain applicable. In any case, however, a property rescuer's recovery would have to be capped by 


\section{International Railway $\mathrm{Co}^{29}$}

In Wagner, plaintiff rescuer was seriously injured in an atteinpt to rescue his cousin who had been thrown froin a moving tram as a result of defendant railway coinpany's negligence. The plaintiff lost at trial, and an intermediate appellate court directed judgment on the verdict for defendant. The Court of Appeals, in an opinion by Justice Cardozo, reversed, rejecting the defendant railway's primary arguments (1) that plaintiff's rescue attempt was outside the chain of causation, and (2) that plaintiff was contributorily negligent, since plaintiff's act was a useless and "wanton exposure to a danger." 30 In a much quoted passage, Judge Cardozo eloquently wrote:

Danger invites rescue. The cry of distress is the summons to rehef. The law does not ignore these reactions of the mind in tracing conduct to its consequences. It recognizes them as normal. It places their effects within the range of the natural and probable. The wrong that imperils life is a wrong to the imperilled victim; it is a wrong also to his rescuer. ${ }^{31}$

The Wagner rule has had universal acceptance. ${ }^{32}$ The only major exception to the rule has been that "professional rescuers [such as firemen and policemen] may not recover for mjuries flowing from risks

the value of the property salvaged. A comprehensive analysis of desirable property rescue reform is beyond the scope of this Comment.

For present purposes, the important distinction between these two groups of cases, however, is that plaintiffs in the first group sought recovery under a restitution theory and lost, while plaintiffs in the second group sought recovery under a tort theory and won. Plaintiffs in the property rescue cases did not seek tort dainages simce the recovery they sought was not cognizable in tort. Tort dainages serve to make deserving plaintiffs whole; thus, a reward for services rendered could not be a proper tort remedy.

See generally W. Keeton, D. Dobbs, R. Keeton \& D. OWen, Prosser AND Keeton on THE LAW OF TORTS $\$ 1$, at 1-7 (5th ed. 1984) [heremafter cited as PROSSER \& KEETON].

As will be demonstrated, infra text accompanying notes $30-41$, 'current tort doctrines favor rescuer claims more than current restitutionary doctrines do. To a significant extent, current tort law already allows a recovery in many cases that would be covered by the proposed reform. This overlap notwithstanding, there are coinpelling reasons to consider these cases under restitution rather than a tort analysis. See infra text accompanying notes $42-45$.

The adoption of this Comment's proposed reform would not lead to all successful rescuers becoming entitled to restitutionary awards. For instance, plaintiffs rescuing life instead of property under the circumstances of Bartholemew or Glenn would have no more success under the proposed reform than under existing restitutionary doctrine. Since the proposed reform adopts a tort-like measure of recovery, those plaintiffs, or any other nonprofessional rescuer, would not receive an award for services rendered, but would only recover any out-of-pocket expenses they might have incurred. Since no expenses were incurred, there would be no recovery. See infra Part III, Section $C$.

29. 232 N.Y. 176, 133 N.E. 437 (1921).

30. Id. at 181,133 N.E. at 438 .

31. Id. at 180,133 N.E. at 437 .

32. See ProssER \& KEETON, supra note 28, § 44, at 307-08. The cases are collected at Annot., 19 A.L.R. 4, 5 (1922) ("The rule is well settled that one who sees a person in imminent and serious peril through the negligence of another cannot be charged with contributory negligence, as a matter of law, in risking his own life, or serions injury, in attempting to effect a rescue, provided the attempt is not recklessly or rashly made."). 
inherent in the act of rescue." tant to the present analysis, is that it need not be a third party defendant's negligence which creates the rescue-inviting danger. With a single exception, ${ }^{34}$ the cases hold that an actor whose own negligence causes a hazardous situation is liable to one who attempts to rescue liim. ${ }^{35}$

It can be argued that the Wagner line of cases that allows an injured rescuer to recover froin a negligent rescuee is not an exception to the common law rejection of externally imposed private liabilities. Since the rescuee's liability rests solely on his own fault in creating the dangerous situation, and not on the benefit conferred, the principle of individual autonoiny is not violated. This argument, lowever, overlooks the larger significance of the Wagner holding, which is that Wagner and its associated cases reflect the assuinption that rescue is a commendable liuman urge to be encouraged, not penalized. ${ }^{36}$ Wagner and its progeny repre-

33. J. Henderson \& R. Pearson, The Torts Process 545 (2d ed. 1981); see Giorgi v. Pacific Gas \& Elec. Co., 266 Cal. App. 2d 355, 360, 72 Cal. Rptr. 119, 123 (1968), where the court adopted the "fireman's rule," stating that "a paid fireman has no cause of action against one whose passive negligence caused the fire in which he was injured." Id.; see also Walters v. Sloan, $20 \mathrm{Cal} .3 \mathrm{~d}$ 199, 571 P.2d 609, 142 Cal. Rptr. 152 (1977) (application of the Giorgi rule to a police officer).

A professional rescuers rule, under which a rescuee would be liable to a professional rescuer for risks independent of the specific emergency that was created negligently by the rescuee, is proposed in Comment, Negligence Actions by Police Officers and Firefighters: A Need for a Professional Rescuers Rule, 66 CALIF. L. REv. 585 (1978).

For criticism of the firemen's rule, see Moss, An Examination of the California Firemen's Rule, 6 PAC. L.J. 660 (1975).

34. Saylor v. Parsons, 122 Iowa 679, 98 N.W. 500 (1904) (an individual cannot be considercd negligent where he incurs danger only to himself, and without negligence there can be no recovery by the rescuer). Saylor is in tune with the line of restitutionary cases discussed supra at notes 20-23 and accompanying text, as illustrated by the Saylor court's statement that the rescuer must rely on "inagnanimity" where the suit is against the rescuee. 122 Iowa at 684, 98 N.W. at 502.

Saylor may be the only case to have reached such a result. Annot., 4 A.L.R.3d 558, 559 (1965). The case has received strong criticism. See, e.g., Britt v. Mangum, 261 N.C. 250, 252-54, 134 S.E.2d 235, 237-38 (1964); see also RESTATEMENT (SECOND) OF TORTS $\S 445$ comment d (1965) (where actor has been negligent, creating a danger to himself, he is hable to those he should reasonably anticipate miglit try to rescue him).

35. See, e.g., Provenzo v. Sam, 23 N.Y.2d 256, 260, 244 N.E.2d 26, 28, 296 N.Y.S.2d 322, 325 (1968); Carney v. Buyea, 271 A.D. 338, 341, 65 N.Y.S.2d 902, 905-06 (1946), motion for leave to appeal denied, 271 A.D.949, 68 N.Y.S.2d 446 (1947); Britt v. Mangum, 261 N.C. 250, 255, 134 S.E.2d 235, 239 (1964); Ruth v. Ruth, 213 Tenn. 82,90, 372 S.W.2d 285 (1963); Longacre v. Reddick, 215 S.W.2d 404, 405 (Tex. Civ. App. 1948). See generally Annot., 4 A.L.R.3d 558, 559 (1965). "[T]here seems to be but little doubt that a rescuer who is injured in reasonably undertaking to save a person who has neghigently imperiled himself may recover from that person." Id. (footnote omitted).

36. In discussing developments of the Wagner rule twenty years later, a commentator observed:

Later cases, like earlier ones, have recognized the humanitarian basis of the "rescue doctrine," so called, and many of them have gone to some length in pointing out that in order to invoke that doctrine successfully and establish freedom from contributory negligence as a inatter of law, it is only necessary for the rescuer to show that he acted as a reasonably prudent person would have acted under the same or similar circumstances ... . and that the law itself makes allowances ... for the human instincts which prompt people 
sent a transformation in the doctrine of contributory neghigence through expansion of traditional notions of foreseeability and causation in order to reach a fair result on the ultimate question of recovery for rescuers. ${ }^{37}$ Thus, these cases ouly superficially rest on notions of fault in creating the dangerous situation.

The underlying pohicies are perhaps best illustrated in a case which preceded Wagner by half a century, Eckert $v$. Long Island Railroad. ${ }^{38}$ The plaintiff's decedent in Eckert died after being struck by defendant's train while the decedent was engaged in the successful rescue of a young child. In upholding a judgment for plaintiff and rejecting defendant's contributory negligence claim, the Eckert court announced the following rule:

The law has so high a regard for human life that it will not impute negligence to an effort to preserve it, unless made under such circumstances as to constitute rashness in the judgment of prudent persons. ${ }^{39}$

The Eckert dissenting opimion clarified the extent of the inajority opinion's inoveinent away from the common law hostility to voluntarisin. ${ }^{40}$ It would have found decedent contributorily negligent and barred plaintiff's recovery:

The act of the intestate in attempting to save the child was lawful as well as meritorious ... but it was not in the performance of any duty imposed by law, or growing out of his relation to the child, or the result of any necessity. There is nothing to rehieve it from the character of a voluntary act, the performance of a self-imposed duty, with full knowledge and apprehension of the risk incurred. ${ }^{41}$

Currently the Wagner rule often leads to the same result as the proposed reform since it is a very rare situation where, under modern tort rules, a rescuer plaintiff cannot establish at least a colorable negligence claim against soine party. ${ }^{42}$ Though the Wagner rule continues to serve a

to attempt to aid others in danger, and itself widens the permissible margin of errors in judginent and immunity from mistakes, requiring a showing of practical certainty of death or injury in order to render a rescuer guilty of contribntory negligence as a matter of law.

Annot., 158 A.L.R. 189, 191 (1945); see also Hope, supra note 13, at 41 (pointing out incongruity that the same kinds of moral acts termed "officious" in the context of a claim for restitution become "reasonable, natural, and proper under the circumstances" in the context of a tort claim).

37. See Annot., 158 A.L.R. 189, 191 (1945).

38. 43 N.Y. 502 (1871).

39. Id. at 506.

40. See supra notes $15-18$ and accompanying text; see also Rudolph, The Duty to Act: $A$ Proposed Rule in THE Good SAMARITAN AND THE LAw 243, 245 (J. Ratcliffe ed. 1966)("[O]f all persons, the volunteer is the least protected by the law.").

41. Eckert, 43 N.Y. at 508 (Allen, J., dissenting).

42. One commentator has proposed expanding tort notions of causation and foreseeability even further, with the result in certain rescue situations of imposing hability without fault on a rescuee for a rescuer's injuries. Epstein, $A$ Theory of Strict Liability, 2 J. LEGAL STUD. 151, 190-93 (1973). For criticisms of Epstein's theory, see Posner, Strict Liability: A Comment, 2 J. Legal STUD. 205 (1973); Comment, supra note 13, at 282-84. 
crucial role regarding the clains of rescuers, the proposed reform would suppleinent and extend its coverage. The proposed reform would improve the functioning of the Wagner rule in several ways. ${ }^{43}$ First, the reform would allow recovery in cases where not even a colorable clain of neghigence could be inade. Second, by eliminating the need for courts to stretch neghigence concepts beyond their breaking point, the proposed reform would lessen the strain on judicial credibility caused by fanciful assignments of negligence, and thus would result in more candid analyses by the courts. ${ }^{44}$ Third, the proposed reform incorporates a reinedy which would allow courts greater flexibility in fashioning a rescuer's award than the all-or-notlimg character of a tort recovery. ${ }^{45}$

In sum, the Wagner rule's significance is that inodern courts, for public policy reasons, make accommodations to traditional tort principles to compensate and reward life rescuers. The saine pohicies should also alter current restitutionary doctrime. ${ }^{46}$ Most significantly, the principles supporting the Wagner rule also militate for the adoption of the proposed reform.

\section{B. The Contract Exception: Postrescue Ratification}

Another context where traditional common law principles have given way to the proinotion of life rescue is when the grateful rescuee agrees after the event to compensate his rescuer. In such cases, courts generally have upheld a plaimtiff rescuer's attempt to enforce such an agreement, despite its unenforceability for lack of consideration under traditional contract rules. ${ }^{47}$

The paradigm case in this area is $W e b b v . M c G o w i n .^{48}$ In $W e b b$, the plaintiff, a mill workınan, had been clearmg the upper floor of the inill in the course of his duties. Plaintiff started to drop a seventy-five pound

43. See infra text accompanying notes 181-225; $c f$. Comment, Rccovery by the Rescuer, 28 LA. L. REv. 609 (1968) (proposal to allow rescuers dual causes of action in tort and restitution).

44. This point is einphatically made by Honore:

[I]n order to afford the rescuer a remedy, courts have ... treated the altruist as if he were simply doing his plain duty and concluded that his action was a necessary consequence of the hazard and so of the fault of the person who created it. But this is just legal fiction.

Honoré, supra note 3, at 231 (footnote omitted) (enphasis added). The proposed reform would eliminate the need for this fiction.

45. See infra Part III, Section $C$.

46. See Hope, Officiousness (pt. 2), 15 CORNELL L.Q. 205, 242 (1930) ([I]t is suggested that the principles governing approved action in an intervenor should be so extended in the direction called for by equity and the true principles of quasi-contractual law, as to insure reimbursement for useful and necessary services reasonably rendered another, though without his request, or ratification, or subsequent promise to pay.").

47. See Webb v. McGowin, 27 Ala. App. 82, 168 So. 196 (1935), cert. denied, 232 Ala. 374, 168 So. 199 (1936); Annot., 8 A.L.R.2d 787, $798-99$ (1949); see also RESTATEMENT (SECOND) of CoNTRACTs $\S 86$ (1981). But see Harrington v. Taylor, 225 N.C. 690, 36 S.E.2d 227 (1945).

48. 27 Ala. App. 82, 168 So. 196 (1935), cert. denied, 232 Ala. 374, 168 So. 199 (1936). 
pine block from the mill floor to the ground below, which was the ordinary method for clearing the floor. As the plaintiff pushed the block over the edge, he noticed the defendant's testator directly below, on the spot where the block would fall if plaintiff took no action. Instead of letting the block fall, and causing the testator certain imjury or death, plaintiff went over the edge with the block, diverting its path away from the testator, who escaped injury. Plaintiff received permanent crippling injuries as a result of the fall, and was unable to work thereafter. To compensate the plaintiff, the testator agreed to pay him fifteen dollars every two weeks for life.

The payments continued for eight years until testator's death. Less than a month after his death, testator's devisees discontinued the payments. Plaintiff brought suit to enforce the agreement, and to recover the unpaid installments. The $W e b b$ court upheld plaintiff's claim, reversing the trial court which had sustained defendant's demurrer.

Under general contract principles, such an agreement would be unenforceable since the testator received no consideration for his promise. ${ }^{49}$ Without bargained-for consideration, there would be nothing to distinguish the promise in $W e b b$ from an unenforceable donative promise. ${ }^{50}$ Yet the $W e b b$ court found that a promise based on a past pecuniary or material benefit was enforceable, stating:

Any holding that saving a man from death or grievous bodily harm is not a material benefit sufficient to uphold a subsequent promise to pay for the service, necessarily rests on the assumption that saving life and preservation of the body from harm have only a sentimental value. The converse of this is true. Life and preservation of the body have material, pecuniary values, measurable in dollars and cents. ${ }^{51}$

Saving an individual's life as a benefit conferred was central to the result in Webb. Thus, though the rescuee had made no prior request, the material benefit received constituted sufficient consideration to support the

49. See Restatement (SECOND) OF CONTRACTS § 71 (1981).

The dominant doctrine in unodern contract theory is the bargain principle. See generally Eisenberg, The Bargain Principle and Its Limits, 95 HARV. L. Rev. 741 (1982). Under this principle, the unsolicited acts of a rescuer could not be consideration for a rescuee's subsequent promise because these acts were not given in excliange for rescuee's promise. The general rule is that past performance is not consideration sufficient to create a binding contract. See RESTATEMENT (SECOND) OF CONTRACTS $\S \S 17(1) \& 71(1)$ (1981) ("[t]o constitute consideration, a performance or a return promise must be bargained for.").

50. See generally J. Calamari \& J. Perillo, The Law of Contracts, $\$ \$ 4-1$ to -2 , (2d ed. 1977). Professor Henderson argues that a gift and promise based on past consideration can and should be distinguished. A promise based on a past benefit is motivated by reciprocity and traditional notions of exchange, while a donative promise or gift is inotivated by benevolence. Henderson, Promises Grounded in the Past: The Idea of Unjust Enrichment and the Law of Contracts, 57 VA. L. REV. 1115, 1158 (1971).

51. Webb, 27 Ala. App. at 85,168 So. at 197-98. 
subsequent agreement. ${ }^{52}$

A credible argument can be made that $W e b b$ is consistent with restitutionary doctrine as traditionally formulated. ${ }^{53}$ It can be argued that plaintiff's recovery in Webb was justified because (1) testator's agreement to compensate plaintiff showed that plaintiff's effort (the "benefit") was desired, ${ }^{54}$ (2) the rate set by the agreenient established a mininuun value which the testator placed on the services, ${ }^{55}$ and (3) the agreenient by the testator to pay and the acceptance of such paynients by plaintiff showed that plaintiff imtended to charge for his acts. ${ }^{56}$

This Comment takes the position that, as with the Wagner rule, ${ }^{57}$ the argument above overlooks the larger significance of $W e b b$, and the Restatement (Second) of Contracts ${ }^{58}$ and statutory provisions ${ }^{59}$ that followed. If the reasoning of the early restitution cases were followed, ${ }^{60}$ the $W e b b$ rule would have never arisen because courts would not have felt compelled to make exceptions to general contract principles in order to avoid inequitable results. Rather, the contrary rule exeniplified by cases like Harrington v. Taylor, ${ }^{61}$ decided ten years after $W e b b$, would be universally accepted law.

In Harrington, the plaimtiff intervened in a domestic squabble, and saved defendant's life by taking an axe blow aimed at defendant's neck squarely on her hand. Defendant agreed to pay plaintiff daniages for her badly mutilated hand, and later paid a small installment. Upon defend-

52. Id.

53. See supra text accompanying notes 25-27.

54. See Note, Promissory Obligations Based on Past Benefits or Other Moral Consideration, 7 U.

CHI. L. Rev. 124, 126 (1939).

55. Id. at 129 .

56. Webb, 27 Ala. App. at 86, 168 So. at 198 (holding that such facts were sufficient to "conclusively [show that] services rendered by [plaintiff] were not gratuitous"). This point will be developed further in Part I, Section $C$ infra. It should be noted that this statement is found at the end of an opinion which contains no other discussion of the point. This statement does, however, directly contradict the irrebuttable presumption of gratuity set up by cases such as Bartholoinew v. Jackson, 20 Johns 28 (N.Y. Sup. Ct. 1822), and Glenn v. Savage, 14 Or. 567, 13 P. 442 (1887). See supra notes $20-23$ and accompanying text. Apparently, the $W e b b$ court unintentionally reached the proper result by allowing the rescuer to determine, after the fact, whether to charge for the rescue.

57. See supra text accompanying note 30-36.

58. RESTATEMENT (SECOND) OF CONTRACTS $§ 86$ (1981).

Section 86 reads:

(1) A promise made in recognition of a benefit previously received by the promisor froin the promisee is binding to the extent necessary to prevent injustice.

(2) A promise is not binding under Subsection (1)

(a) if the promisee conferred the benefit as a gift or for other reasons the promisor has not been unjustly enriched; or

Id.

(b) to the extent that its value is disproportionate to the benefit.

59. See, e.g., Cal. Civ. Code § 1606 (West 1982); N.Y. Gen. Oblig. LAw § 5-1105 (McKinney 1978).

60. See supra notes $20-23$ and accompanying text.

61. 225 N.C. 690,36 S.E.2d 227 (1945). 
ant's default, plaintiff brought suit to enforce the agreement. In affirming a judgment that sustained defendant's deinurrer, the Harrington court concluded:

The Court is of the opinion that however much the defendant should be impelled by common gratitude to alleviate the plaintiff's misfortune, a humanitarian act of this kind, voluntarily performed, is not such consideration as would entitle her to recover at law. ${ }^{62}$

The modern trend is to reject the Harrington court's adherence to the common law disfavor with the claims of rescuers. Most modern courts have adopted the $W e b b$ contract exception, which represents a favorable attitude toward the claims of rescuers. ${ }^{63}$ One rationale for $W e b b$ and its subsequent codification in section 86 of the Restatement (Second) of Contracts is illustrated by the comments of Professor Braucher who observed that, regardless of the legal doctrine utilized, most courts would reach the saine result as $W e b b$ on similar facts.

What you have, really, is a line of distmction between essentially gratuitous transactions and cases which are on the borderline of quasi-contracts, where promise removes the difficulty which otherwise would bar quasi-contractual rehief. ${ }^{64}$

As Professor Braucher's statement indicates, the most serious barrier to a rescuer's recovery under modern restitutionary doctrine is the presumption of gratuity. ${ }^{65}$ Under the doctrine as developed in the early restitution cases, ${ }^{66}$ this presumption was irrebuttable. ${ }^{67}$ Later, when the conclusiveness of the presumption was relaxed, the rescuer was still required to estabhish that he intended to charge before he rendered his services. ${ }^{68}$ This required evidentiary showing was both burdensome and counterintuitive. ${ }^{69}$ In the usual case, a nonprofessional rescuer will have

62. Id. at 691,36 S.E.2d at 227 (emphasis added).

63. That $W e b b$, rather than Harrington, represents the preferred modern rule is clear. One commentator has written:

[T] he trend of modern authorities is definitely to the effect that . . a moral obligation is sufficient to support an executory promise where the promisor has originally received from the promisee something of value in the form of a pecuniary or material benefit, under such circumstances as to create a moral obligation on the part of the promisor to pay for what he received, even though there was no antecedent or contemporaneous promise or request, and no legal liability at any time prior to the subsequent express promise.

Annot., 8 A.L.R.2d 787, 798 (1949). For a collection and discussion of the many cases so holding, see $i d$. at 789-803. See also RESTATEMENT (SECOND) OF CONTRACTS $\S 86$ (1981).

64. 42 A.L.I. Proc. 274 (1965).

65. See supra note 56; infra Part I, Section $C$.

66. See supra notes 20-23 and accompanying text.

67. See F. WOODWARD, THE LAW OF QUASI-CONTRACTS $\S$ 201, 206-07 (1913); see also Wade, supra note 17, at 1192 ("[T] lie presumption is treated as a rule of law" in certain cases.). Woodward's views are criticized in Hope, supra note 13, at 37 n.35.

68. See Hope, supra note 13, at 37-38.

69. See R. GOFF \& G. JONES, supra note 15, at 271 ("[T]lis burden of proof is unnecessarily severe and should not be placed on the [rescuer]. A person who intervenes in an einergency will 
given no thought to possible compensation or even have estimated the extent of his expenses until after the services have been rendered.

The $W e b b$ rule alters this requirement; the rescuer's intent to charge is deemed established by his acceptance of rescuee's offer of remuneration after the rescue. ${ }^{70}$ By the same token, in the context of a claim for restitution, the rescuer's intent to charge should be established by the very fact that he has brought suit. ${ }^{71}$

If the $W e b b$ rule is proper, the social policy that favors generosity to rescuers of human life cannot be limited only to situations where there has been post-rescue ratification. In Webb, as in Wagner and Eckert, a court circumvented well-established legal rules in order to allow recovery by a deserving injured rescuer. Explicit in the Webb result is the judginent that, irrespective of rescuee's assent, successful rescue is a clear "Inaterial, pecuniary" benefit. ${ }^{72}$ Thus, the $W e b b$ policy of generosity to rescuers should extend to all situations where a nonnegligent rescuer's efforts have conferred a clear benefit on a rescuee, and the rescuer has suffered an injury in the process. ${ }^{73}$

\section{The Restitution Exception: Recovery for Professional Rescuers}

The previous two sections have dealt with ways that the coinmon law harshness towards the claims of rescuers has been mitigated. The Wagner rule shows how tort doctrines have been inodified im favor of such claims; the $W e b b$ rule shows how contract doctrines have been modified to the same effect. Under pure restitution doctrine, there also developed another early exception to the rule of nonrecovery for rescuers. This exception, which also met with universal acceptance, ${ }^{74}$ allows professional rescuers, such as doctors and hospitals, to recover the value

rarely consider, at the time of intervention, whether he should charge for his services or seek reimbursement for his expenses.").

70. See Webb, 27 Ala. App. at 86, 168 So. at 198.

71. Cf. Hope, supra note 13, at 38 (rescuers or others making a claim for restitution should be able to determine for themselves what they wish to donate and what they wish to be reimbursed for free of the presumption of gratuity).

72. Webb, 27 Ala. App. at 85, 168 So. at 198.

73. Of theoretical interest is the possibility that a rescuee's offer of remuneration as in Webb might limit a rescuer's recovery. This apparent conflict can be resolved as follows. Since the nature of a $W e b b$ recovery is contractual, a rescuer who feels that rescuee's offer is insufficient would be free to reject the offer, and no contract would be formed. In such a situation, the rescuer would still have the option of bringing suit under a restitutionary theory. This set of options, settling for less than the full amount of one's claims or undertaking the risk of litigation in the hope of full recovery, presents the same choices faced by private plaintiffs generally.

74. See, e.g., Cotnam v. Wisdom, 83 Ark. 601, 104 S.W. 164 (1907); In re Crisan Estate, 362 Mich. 569, 107 N.W.2d 907 (1961); Sceva v. True, 53 N.H. 627 (1873); see also RESTATEMENT OF RESTITUTION §114 comment c, \$116 comment a (1937); RESTATEMENT (SECOND) OF RESTITUTION $\S 1$ comment h, illustration 10 (Tent. Draft No. 1, 1983). 
of their services rendered, as measured by their normal fees, even when the rescue attempt fails.

The leading case is Cotnam v. Wisdom. ${ }^{75}$ In Cotnam, plaintiff doctors treated the unconscious victim of a street car accident who died without regaining consciousness. Plaintiffs sued decedent's estate to recover their customary fees. Despite the lack of assent on decedent's part, the court confirmed plaintiff's right to recover, stating:

We regard it as well settled by the cases ... that an insane person, an idiot, or a person utterly bereft of all sense and reason by the sudden stroke of an accident or disease may be held hable, in assumpsit, for necessaries furnished to him in good faith while in that unfortunate and helpless condition. ... The defendant's counsel says it is usurpation for the court to hold, as a matter of law, that there is a contract and a promise when all the evidence in the case shows that there was not a contract, nor the semblance of one. It is doubtless a legal fiction, invented and used for the sake of the remedy. If it was originally usurpation, certainly it has now becoine very inveterate, and firmly fixed in the body of the law. ${ }^{76}$

The Cotnam court emphasized that the reasons upon which this "usurpation" were based were "too sensible and humane, to be overborne by any ... refined logic" founded on the mere absence of an express contract or promise. ${ }^{77}$ The Cotnam rule allows courts to find an implied-m-law contract to pay for medical services where, due to the nature of the emergency, the recipient of the services was unable or incompetent to give the assent required for the formation of an actual contract. ${ }^{78}$

As Professor Palmer indicates, courts have dispensed witl the assent requirement regarding the restitutionary claims of doctors for reasons of public policy:

If the services were in an attempt to preserve life or health, restitution of their value will almost certainly be granted. The public interest in the protection of life or health or, as the Restatement says, in preventing another froin "suffering serious bodily harm or pain," is strong enough to override the judicial reluctance to create a legal obhigation to pay for goods or services transferred to a person without his request. ${ }^{79}$

One unfamiliar witli the intricacies of legal doctrine miglit reason that the public interest in life preservation should not in any way depend on the rescuer's possessing a medical degree, or professional status. The unfamiliar observer would thus be puzzled by the way a rescuer's

75. 83 Ark. 601, 104 S.W. 164 (1907).

76. Id. at 605,104 S.W. at 165 (quoting Sceva v. True, 53 N.H. 627 (1873)).

77. Id. (quoting Sceva v. True, 53 N.H 627 (1873).

78. A similar result was reached in In re Crisan Estate, 362 Mich. 569, 107 N.W.2d 907 (1961), where a hospital was able to recover its fees for eleven months of treatment from the estate of a comatose patient who died without regaining consciousness.

79. 2 G. PALMER, supra note $6, \S 10.4$, at 376 (footnote omitted). 
chances of recovery turns on the possession of such a credential. ${ }^{80}$ Supporters of this rule, however, would emphasize that there is a greater public interest in doctors undertaking rescue attempts because their skill and training are needed in many rescue situations where even the most competent nonprofessional rescuer's efforts would be to no avail. Since doctors' services would be more likely to be effective, there are sufficient policy reasons to override the fundamental presumption of gratuity regarding a doctor's rescue services that are not present regarding a nonprofessional's rescue services.

Supporters also argue that since a doctor's livelihood may consist of performing the same sort of services that he has rendered in a rescue situation, a court can safely presume that he intended to charge for his services. ${ }^{81}$ Moreover, there is hittle problem in valuing a doctor's services, since a court can correctly assume that the measure of the rescuee's enrichment is merely the doctor's regular fees for treating a patient. ${ }^{82}$

Professor Landes and Judge Posner suggest that the allowance of a recovery to doctors for rescue services, while denying such recovery to nonprofessionals, may have an economic rationale. ${ }^{83}$ They propose three reasons im support of allowing recovery only to doctors. First, "[b]oth the opportunity cost of [a doctor's] time and the amount of time" he must provide in performing a rescue are likely to be greater than those of a nonprofessional. ${ }^{84}$ Second, the greater cost to a physician "reduces the likelihood that altruism alone would prompt him to [perform the rescue]." ${ }^{85}$ Third, "the costs to the legal system of determining an appro-

80. A cynic might speculate that allowing only those rescuers who are also doctors to recover might have less to do with the public interest than with political influence. Landes and Posner, who support the allowance of a rescue recovery only to doctors on the basis of econounic efficiency, give the medical profession's political power as the explanation for the prevalence of "Good Saunaritan" statutes that excuse doctors from liability for ordinary negligence in rescue situations. Landes \& Posner, Salvors, Finders, Good Samaritans, and Other Rescuers: An Economic Study of Law and Altruism, 7 J. LEGAL STUD. 83, 127 (1978) ("Perliaps tliese statutes are to be explained-as so much legislation is to be explained, including other legislation affecting physicians-by the political powcr of the beneficiaries rather than by the community's interest in promoting efficiency."); see also infra note 83 and accompanying text.

81. See Restatement of Restitution $\$ 114$ comment c (1936) ("The fact that the person acting is in the business of supplying the things or is acting in the course of his profession, is evidence of an intent to charge.").

82. See Wade, supra note 17 , at 1187.

83. See Landes \& Posner, supra note 80, at 109-10. Indeed, the authors' basic thesis is much broader-they posit that the whole body of common law relating to rescue and salvage is commendable; and that these doctrines can be objectively and independently derived through economic analysis. This thesis has received much criticism from other commentators. See, e.g., 2 G. PALMER, supra note 6, $\S 10.3$, at 46 (Supp. 1984) (finding Landes and Posner's economic analysis of these issues "unpersuasive"); Eisenberg, supra note 49, at $758 \mathrm{n} .53$ (finding Landes and Posner guilty of overly creative case interpretation and faulty logic).

84. Landes \& Posner, supra note 80 , at 110.

85. Id. 
priate award are lower in the professional's case: the award can virtually be read off the physician's fee schedule." 86

These arguments ignore the distinction between the typical recoveries sought by a professional and a nonprofessional rescuer. Professional rescuers generally seek to recover compensation for their services, while nonprofessional rescuers sue for their expenses, broadly defined to include physical injuries incurred in the rescue attempt. ${ }^{87}$ Whatever public policy may support allowing only professional rescuers an award for the value of their services ${ }^{88}$ does not apply to the reimbursement award of expenses to nonprofessional rescuers, which is the proposal advocated here. ${ }^{89}$

At the root of the recovery problem is the presumption that a nonprofessional rescuer intends to act gratuitously. ${ }^{90}$ Even if not wholly irrebuttable,$^{91}$ this presumption actually inakes it nearly impossible for the nonprofessional rescuer to recover. ${ }^{92}$ The usual rationale for the presumption of gratuity is that the inotivating force behind nonprofessional rescue is altruism, and that "a person who acts entirely froin inotives of humanity is not entitled to restitution."93 Yet this is a questionable assumption about human nature. As Professor Hope notes, "it may be claimed on the basis of what seeins to be rather general experience that it is quite as normal, liuman nature being what it is, to want solnething for nothing as it is to want nothing for something." 94

Secondly, even to the extent the presuinption can be rebutted, it still

86. Id.

87. Cf. supra note 28.

88. A professional rescuer's fee for services would reasonably take into account his expensesthus the professional rescuer may be able to rccover his expenses even without the proposed reform. Of course, what is imcluded in the definition of expenses is crucial. See infra notes $105 \& 216$.

89. See R. GoFF \& G. JONES, supra note 15 , at $272-73$.

90. The presumption has had more than its share of criticism. See, e.g., R. GoFF \& G. JoNES, supra note 15, at 272-73; 2 G. PALMER, supra note 6, § 10.3, at 369-70 \& n.6; Bickenbach, supra note 13, at 214-16; Honoré, supra note 3, at 231-38; Hope, supra note 13, at 36-38; Wade, supra note 17, at 1192-93 \& n.52. But see Dawson, Rewards for the Rescue of Human Life? in THE GooD SAMARITAN AND THE LAW 63, 83-89 (J. Ratcliffe ed. 1981); Landes \& Posner, supra note 80, at 109-12. This Comment argues that the presumption should be reversed. See infra note 106-10 and accompanying text.

91. Compare 2 G. PALMER, supra note $6, \S 10.3$, at 370 (footnote omitted) (The suggestion that in rescue situations "there is an irrebuttable presumption that the services were intended to be gratuitous ... should be rejected."), with Landes \& Posner, supra note 80, at 109 n.60 ("The case law appears to ... . make the presumption of no intent to charge irrebuttable, with the result that the nonprofessional rescuer is never entitled to a monetary reward."). See also supra note 67.

92. See supra note 69. The presumption, to the extent even considered in $W e b b$, was glossed over by the Webb court. See supra notes 67-71 and accompanying text.

93. RESTATEMENT OF RESTITUTION $\$ 114$ comment $c$ (1936); see also RESTATEMENT (SECOND) OF RESTITUTION $\S 3$ comment c (Tent. Draft No. 1, 1983) ("It is virtually a precept that the merit of emergency salvage efforts is, and should be, its own reward.").

94. Hope, supra note 13 , at 37 n.35. 
imposes a nearly impossible evidentiary burden ${ }^{95}$ on the nonprofessional rescuer. Furthermore, the presumption lumps all such rescuers together for reasons no better than administrative convenience and a reluctance to reward voluntarism. Professor Hope writes:

There is, it is submitted, no good reason for dealing with these cases in this, as it may be termed, "steam-roller" fashion. It seeins to be, really, a rather uncandid way of proceeding. The court, perhaps shutting its eyes to good evidence to the contrary, gratuitously attributes to $\mathrm{A}$ the high Christian virtue of a pure altruisin that he never claimed and does not want attributed to him. On the contrary, A wants a reasonable return on his effort for $B$, and if he has not been inexcusably officious, he should have that, and not words of commendation for a virtue he does not profess. It really has the effect of punishing $\mathrm{A}$, just as much as if upon satisfactory evidence the court had found him to have been officious and deried him a recovery on the ground. And yet $\mathrm{A}$ is, excluding officiousness, not blameworthy in intending merely an advance of his time, labor, or money in B's interest, rather than an outright gift of these. Surely one has a right to measure the extent of what he is willing to do for another without being made to forfeit what he has given on the pretext that he intended to give wholly without return. ${ }^{96}$

Another argument against compensation for nonprofessional rescuers has been made by the drafters of both the Restatement and Restatement (Second) of Restitution. Just as one who gives a gift is not entitled to restitution if he later attempts to rescind his act, a rescuer who undertakes a rescue with no imtent to charge may not afterwards seek conipensation. ${ }^{97}$ This argument fails because typically rescue and gift situations are too dissimilar to support the analogy.

In the typical gift situation involving a tangible good, the gift becomes the donee's absolute property immediately upon conferral, to do with as he pleases. ${ }^{98}$ Once this occurs, the source of this property

95. Id. (criticizing F. WoODWARD, supra note 67) ("the absence of any evidence of A's intention to charge $B$ for service in any particular case is not equivalent to the fact of there being no such intention on his part." (einphasis in original)). See also supra note 69.

96. Hope, supra note 13, at 37-38 (emphasis in original); see also Bickenbach, supra note 13, at 215 ("If the plaintiff acted spontaneously, there is no rcason to suppose he assumed this risk [of performing his services for free] .... [T] he court should allow the plaintiff the benefit of the doubt on the question of the risks he was assuming ....").

Honoré inakes an analogous point in criticizing those, like Dawson, supra note 90 , who would bar all private recoveries for unsolicited life rescue by a nonprofessional on the grounds that virtue is and should be its own reward. This attitude, Honore points out, has the effect of forcing altruism on a rescuer whether or not it is desired or intended: "Surely the argument is obtuse. No one is compelled to claim a reward he does not want. [The rescuer] . . . can preserve immaculate his moral idealism if he wishes. No one can be compelled to be compensated." Honoré, supra note 3, at 234.

97. See RESTATEMENT OF RESTITUTION $\S 1$ cominent c (1936); RESTATEMENT (SECOND) OF RESTITUTION $\$ 2$ comment c (Tent. Draft No. 1, 1983).

98. See J. Calamari \& J. Perillo, supra note 50, § 4-4, at 139 n.45; see also Hoffman v. Wausau Concrete Co., 58 Wis. $2 d$ 472, 484, 207 N.W.2d 80, 86 (1973) (listing the four elements of a 
becomes irrelevant; the donor has no greater claim to that which he gave than does the rest of the world. In contrast, rescue does not involve a tangible piece of property. ${ }^{99}$ Furthermore, the circumstances surroundmg the conveyance of property in a gift setting support the presumption of gratuity. In the rescue setting, the rescuee will not know essential facts pertaining to the rescuer's imtent to charge or act gratuitously until after the rescue attempt. For instance, the rescuee must wait until the danger has passed to find out whether the rescuer is a professional or a nonprofessional, and whether the rescuer intends to charge or act gratuitously. Thus, the extent of rescuee's "property right" in rescuer's services can only be determined from the circumstances of the rescue. ${ }^{100}$ Since the rescuee's property right only is identified after the rescue, the determination whether or not the rescuer intended to charge should also be made at that point.

In emergency rescue situations, where immediate reflex action is required, the whole notion of a pre-rescue "intent to charge" is a legal

gift as intent to give, actual or constructive delivery, termination of the donor's dominion, and dominion in the donee).

99. The distinction between tangible and intangible property lias significance not only in the gift context, but for all restitntionary claims for services rendered. See generally Jones, supra note 26. The key point is that if tangible property is gratuitously conferred the beneficiary need only return the property to avoid liability. There is no such easy solution where the gratuitous benefit consists of services. See id. at 273-76; see also infra Part III, Section $C$.

It inust be remembered that, as to the gift of services, a preliminary step before reaching the question of intent to cliarge, nnder botl current law and the proposed reform, is that the rescuer inust establish that his intervention was justified under the circunstances, i.e., that the rescue was necessary and that the failure to obtain rescuee's consent was excusable. Where the rescuee's consent was obtained, the rescuee requested the services, or the rescuee freely accepted the services knowing of rescner's intent to clarge, the rescuer can recover a quasi-contractual award for the value of his services under current law. If the rescuer fails to carry this burden of proof, his acts are properly deemed "officious," and he is not entitled to restitution.

100. In the event any potential rescuee possesses sufficient sarigfroid to refuse rationally the proffer of nongratuitous services in the lope of a free rescue, or for any other legitimate reason, the proposed reform would deny the rescuer a recovery for services performed over rescuee's objeetion. But the rescuee's objection in and of itself is not sufficient to prevent rescuer's recovery. In cases involving suicide attempts or willfnl endangerment, the "danger invites rescue" rule of Wagner would allow the rescuer a tort remedy, regardless of rescuee's objections. See Talbert v. Talbert, 22 Misc. 2d 782, 199 N.Y.S.2d 212 (1960) (plaintiff son's complaint stated a cause of action against defendant fatler where son liad suffered imjuries while successfully preventing father's suicide); see also supra text aecompanying note 31 .

In cases where rescuee's refusal is irrational, such refnsal is incompetent and rescuee's assent will be inphied-in-law under one branch of the Cotnam rule. See, e.g., Matleson v. Smiley, [1932] 2 D.L.R. 787 (a Canadian casen which held a doctor who unsnccessfully attempted to revive a suicide was entitled to remuneration from snicide's estate).

In the somewhat fanciful case where a rescuee rationally refuses a proffer of services to avoid liability for restitution knowing that rescuer will ignore his spurious objections, rescuer could attempt to slow: (1) that the rescuee's refusal was irrational and thus inoperative under the Cotnam rule (obversely rescuer could show that the objections were not genuine becanse if genuine such objections would have been irrational); or (2) that rescuee knew that rescuer would ignore the objeetions, and thus, in effect, there was a free acceptance of the services rendered. 
fiction. ${ }^{101}$ Realistically, ${ }^{102}$ the rescuer in such situations will likely have no time to calculate inore than what actions are required to effect the rescue. ${ }^{103}$ As a inatter of social policy, even assuming that legal doctrine can affect what is essentially instinctual behavior, rescuers should not be encouraged to think about their "intent to charge," before or during the rescue atteinpt because such thoughts inay well detract from the rescue effort.

Moreover, there are practical reasons for resolving the issue of gratuity after the fact. First, the parameters of a rescue may not be apparent at the outset. A rescuer who intended to donate one hour of his tiine to a rescue effort should not lose his claim to all compensation on account of his initial generosity when the effort instead takes four days. ${ }^{104}$ By the same token, a rescuer who intended to make a gift of his services, should not lose his right to reimbursennent on account of this benevolence when he incurs substantial expenses, whether fiscal outlay or physical injury, during a rescue attempt. ${ }^{105}$ It is as if a philanthropist who had donated $\$ 50,000$ to an orphanage were legally required to contribute an additional $\$ 500,000$ because otherwise the orphanage would go bankrupt and the original bequest would be wasted.

The most frequently reported situation, and the cause of most concern, is where the nonprofessional rescuer does not know the rescuee

101. See Bickenbach, supra note 13, at 215 ("[C]ourts have tended to misuse this reasoning. Spontaneous aid need not be altruistic; yet courts often equate the two by raising the presumption of gift giving in emergency situations.").

102. See generally Note, The Duty to Rescue in Tort Law: Implications of Research on Altruism, 55 IND. L.J. 551 (1980).

103. See supra note 69 and accompanying text.

104. See supra text accompanyiug note 96 . Under tort prineiples, once one undertakes a rescue attempt, he risks incurring substantial tort liability if he later abandous the attempt. See Lacey v. Umited States, 98 F. Supp. 219, 220 (D. Mass. 1951) (United States Coast Guard not liable for negligently failing to rescue airplane pilot lost at sea in the absencc of a showing that the rescue had reached the stage "where other would-be rescuers were induced to cease their efforts in the belief that the Coast Guard had the situation in hand.'); Farwell v. Keaton, 396 Mich. 281, 240 N.W.2d 217 (1976) (\$15,000 award upheld against decedent's social companion who administered to decedent's fatal wounds but who negligently failed to obtain medical assistance or at least notify someone of decedent's condition and whereabouts); see also RESTATEMENT (SECOND) OF TORTS $\S 322$ (1977). Under current law, therefore, one who undertakes a rescue gratuitously, which is presumed in the case of a nonprofessional, can theoretically be locked involuntarily into completing the rescue, without claim to compensation, no matter how long the rescue takes. Whether a modern court would actually reach such a result, however, is highly questionable.

105. McCamus, supra note 15 , at 312 . Goff and Jones also strongly endorse this point, although they would redefine "expenses" to exclude any "loss suffered" in the rescue attempt. R. GoFF \& G. JONES, supra note 15, at 272-73. This Comment argues that, although such a half-way measure is an understandable attempt to limit a rescuee's otherwise substantial potential liability, no principled distinction can be made between cash outlays (the only item clearly within Goff and Jones's conception of "expenses") and, for instance, a broken arm (which Goff and Jones specifically exclude as an item of expense). Under general tort principles, medical expenses and loss of earnings resulting from physical mjuries are both considered properly recoverable out-of-pocket expenses. See RESTATEMENT (SECOND) OF TORTS § 924 (1979). 
before the services are rendered. In this situation, the presumed presence of either an "intent to charge" or an "intent to act gratuitously" formed prior to the rescue is a legal fiction. The results of the two presumptions are, however, vastly different. If, as under current law, the rescuer is presumed to act gratuitously uuless he intends otherwise, and if the rescuer must form his intent to charge prior to the rescue, then, unless the rescuer knew the rescuee and the rescuee's financial status beforehand, the rescuer would never be able to meet the requirements for recovery. But if, as under the proposed reform, the rescuer is presumed to intend to charge uuless he indicates otherwise, the rescuer could reach an actual, informed decision regarding whether to pursue recovery after the rescue, with the knowledge of the rescuee's financial resources and of his own expenditures. ${ }^{106}$

In re Crisan Estate ${ }^{107}$ illustrates this point. In Crisan, decedent had collapsed in a public supermarket and was taken to a state-run hospital. Eleven months later, decedent died without regaining consciousness and without paying for the hospital's services. After decedent's death, the hospital administration discovered that the decedent owned property. Only at that point did the hospital attempt to recover its fees froin the decedent's estate. ${ }^{108}$

The Crisan court gave no consideration to the hospital's "intent to charge" in upholding the hospital's recovery. This omission was likely due to the fact that, even under current law, professional rescuers are presumed to intend to charge for their services. ${ }^{109}$ Assuming that doctors and hospitals provide the saine emergency rescue services to all rescuees without reference to a rescuee's ability to pay, and without losing their claim to fees if the rescuee has sufficient funds, a nonprofessional rescuer should have the same privilege since the nonprofessional will also provide ennergency assistance without knowing the financial status of the rescuee. The result in Crisan deinonstrates that rescue cases can be decided without requiring a fictive pre-rescue intent to charge. ${ }^{110}$

106. Theoretically, it would also be possible to "divide" the presumption by assuming that a rescuer would intend to charge only the rescuees that have the resources to pay for the rescue expenses. There is no social policy that should prevent a rescuer from charging for rescue services that would have to be gratuitiously rendered to an indigent.

The changed presumption would not reduce the number of gratuitous rescues attempted and would encourage an increase in the number of overall rescues attempted. Furthermore, by adopting the proposed reform's complete presumption to charge, the fiction of a pre-rescue intent is avoided without permitting any unjust enrichment.

107. 362 Mich. 569, 107 N.W.2d 907 (1961).

108. Id. at 571,107 N.W. $2 \mathrm{~d}$ at 908 . It is easy to imagine that whether a rescuer seeks compensation would depend in part on the rescuee's financial status. No potential plaintiff would pursue a claim against a defendant known or thought to be judgment-proof due to insolvency.

109. See Cotnam v. Wisdom, 83 Ark. 601, 104 S.W. 164 (1907).

110. To the extent that the rescuer did wish to act gratuitously, the rescuer could refuse any offer of remuneration, sign a waiver of any claim, fail to bring an action for recovery, or only seek 
A related version of the problem has found exphicit treatment in general restitutionary law. Section 26 of the Restatement of Restitution, entitled "Mistake in Making Gifts," reads:

(1) A person is entitled to restitution from another to whom gratuitously and induced thereto by a inistake of fact he has given money if the mistake

(a) was caused by fraud or material misrepresentation, or

(b) was as to the identity or relationship of the donee or as to some other basic fact, or

(c) was as to the amount given or as to the basis upon which the amount was computed.

(2) In the absence of fraud, a donor who has made a basic mistake as to the amount of a gift is entitled to restitution of the surplus only.

(3) A person who has transferred money to another without intention to make a gift thereof may be entitled to restitution although at the time of transfer he manifested that the money was transferred as a gift. ${ }^{111}$

Section 26 is limited to monetary gifts, but its underlying principles can be applied to rescue situations. For example, a rescuer who intended to donate one hour of services and imstead rendered four days of services should obtain restitution for the surplus services by analogy to section 26(2). The amount to be recovered would be ineasured by the difference between the value of four days of services and one hour of services. Similarly, by analogy to section $26(1)$ (b), a rescuer who would have expected no monetary reward for his services from a destitute rescuee, should be entitled to at least soine restitution if the rescuee turns out to have some assets. $^{112}$ Thus, the reversal of the presuinption of gratuity, as suggested by this Comment, actually represents merely an extension of basic restitutionary principles.

In sum, the consequences of the presumption of gratuity are grossly mequitable. Regarding spontaneous rescues, the presumption is a legal fiction that denies recovery to deserving claimants. ${ }^{113}$ The presumption niay operate to compel "gifts" of services rendered and expenses incurred far above the level a rescuer may have intended. The presumption would also prevent a rescuer from claiming restitution from a solvent rescuee, even if the rescuer only had no mtent to charge an assetless rescuee. Most modern commentators who have considered this question are criti-

partial recovery of his expenses. Thus, the proposed reform would allow a valid and informed act of gratuity to be accomphished without presuming that all rescuers intended to act that way.

111. RESTATEMENT OF RESTITUTION $\$ 26$ (1937).

112. A successful rescuer who meets all the other criteria of the proposed reform would be able to recover something from any solvent rescuee. However, as is explained infra in Part III, Section $C$, the reform requires a court to consider a rescuee's fiuancial circumstances. Thus, a rescuee would not suffer undue financial hardship as a result of liability imposed by the reform.

113. See supra note 69 . 
cal of the presumption as it is currently employed. ${ }^{114}$ Current restitution doctrine does allow claims in the logically related context of inonetary gifts inade where there was a mistake as to the amount given or the identity of the donee. ${ }^{115}$ The single reforn most strongly urged by this Coin- . inent is the reversal of the presumption of gratuity.

\section{II}

\section{Civil and Maritime Law: The Rescuer as Manager OR SALVOR}

Part I outlined the common law hostility to rescuers, and argued that such hostility was inconsistent with other common law doctrines and with public policy concerns. Part II will demonstrate how systems of Western law have long imcorporated doctrines which offer strong encourageinent to rescue efforts which are "voluntary," unsolicited or noncontractual. These systems do not treat all such efforts as gratuitous. The two major inodels referred to in this Part are the civil law doctrine of negotiorum gestio and the maritime law doctrine of salvage.

\section{A. Civil Law: Negotioruin Gestio ${ }^{116}$}

The legal issues addressed by this Comment rarely arise in most European countries because their civil law systems already possess a legal inechanisin which applies to rescue. This mechanism, originatiug in early Roman law, is called negotiorum gestio. ${ }^{117}$ The essence of negotiorum gestio is an imphed-in-law agency relationship.

The Institutes of Justinian describe the operation of negotiorum gestio as follows:

Thus, if one man has managed the business of another during the latter's

114. See supra note 90.

115. See supra text accompanying note 111.

116. A translation from the Latin might read "management of another's affairs." See Dawson, supra note 1 at 817,818 ; see also S. STOLJAR, supra note 13, at 188-89.

117. The leading American works describing the origins and modern workings of negotiorum gestio are Dawson, supra note 1 at 817, 1073; Lorenzen, The Negotiorum Gestio in Roman and Modern Civil Law, 13 CoRNell L.Q. 190 (1928). Additional sources include J. Dawson, UNJUST ENRICHMENT-A COMPARATIVE ANALYSIS 55-61, 136-40 (1951); Heilinan, The Rights of the Volunteer Agent Against His Principal in Roman Law and in Anglo American Law (pts. 1 \& 2), 4 TENN. L. REv. 34, 76 (1925-1926); Comment, Management of the Affairs of Another, 36 TuL. L. REV. 108 (1961).

For the interesting, if strained, argument that English common law has largely adopted negotiorum gestio principles under various labels, see Marasinghe, The Place of Negotiorum Gestio in English Law, 8 OTTAWA L. REv. 573, 586 (1976) ("English law does not in fact deny a remedy in circumstances where the civilian doctrine of negotiorum gestio would apply."); see also Birks, Negotiorum Gestio and the Common Law, 24 CURRent Legal Probs. 110 (1971) (making a similar, though less far-reaching argument). But see R. GOFF \& G. JONEs, supra note 15, at 263 ("[T] great majority of common law jurisdictions, including England, appear to have rejected any notion of negotiorum gestio...."). 
absence, each can sue the other by the action on uncommissioned agency; the direct action being available to him whose business was managed, the contrary action to him who managed it. It is clear that these actions cannot properly be said to originate in a contract, for their peculiarity is that they lie only when one man has come forward and managed the busmess of another without having received any commission so to do, and that other is thereby laid under legal obligation even though he knows nothing of what has taken place. ${ }^{118}$

In direct contrast to the common law hostility to "officious intermeddlers" and "mere volunteers," negotiorum gestio offers a direct reinedy for those who have acted on another's behalf or in his interest, even if such actions were unsolicited. The classical rationale for allowing the gestor, the unsolicited manager, snch a claim is as follows:

The reason of this is the general convenience; otherwise people might be summoned away by some event of pressing importance, and without commissioning anyone to look after and manage their affairs, the result which would be that during their absence those affairs would be entirely neglected; and of course no one would be likely to attend to them if he were to have no action for the recovery of any outlay he might have mcurred in so doing. ${ }^{19}$

Reading "general convenience" to mean "public policy," the encouragement of socially useful actions by allowing a legal claim for coinpensation and expenses is equally applicable to rescue situations. ${ }^{120}$ Indeed, the apphicability of negotiorum gestio to rescue situations has been specifically approved im a number of modern cases. ${ }^{121}$

Roman civil law imposed six prerequisites to a claim of negotiorum gestio. ${ }^{122}$ These prerequisites were:

1. the actor (the "agent") must have managed another's (the "principal's") affairs for the principal's benefit;

2. the agent must have been under no duty, contractual or otherwise, to perform the acts for which the clann is made;

3 . the agent must have acted with the expectation of receiving reimbursement for his expenses;

4. the agent could not receive reimbursement if his management was contrary to the express wish of the principal;

5. the agent's acts must have benefitted the principal, or would have had they been successful;

6. the agent's acts must have taken place under circumstances such that

118. INST. JUST. 3.27.1, reprinted as translated in J. SCOTT, CASES ON QUAS1 CONTRACTS 1 (1932).

119. Id.

120. See Dawson, supra note 1, at 1095 (observing that rules of negotiorum gestio "were justified essentially by a moral ideal which placed a high value on disinterested services to others").

121. See id. at 1095-1127 (collection and discussion of cases).

122. See Lorenzen, supra note 117, at 191-97. 
the agent's intervention was reasonable. ${ }^{123}$

Of these requirements, (3) and (5) are of particular interest.

Requirement (3) seems to be the civil law analog to the common law requirement of estabhshing an "intent to charge" as a prerequisite to recovery. This common law requirement has had the undesirable effect of barring restitutionary claims of nonprofessional rescuers. ${ }^{124}$ As will be demonstrated, ${ }^{125}$ however, the negotiorum gestio parallel has not had such effect, because the presumption not to charge in negotiorum gestio cases traditionally was limited to the services rendered, ${ }^{126}$ and the agent was presumed to have imtended to seek reimburseinent for expenses mcurred. ${ }^{127}$

Requirement (5) allows the agent to establish a negotiorum gestio claim even if the actions were not successful in conferring a benefit on the principal. Thus a negotiorum gestio claim can resemble one made under the Cotnam rule, ${ }^{128}$ where a rescuee imcurs hability to a rescuer even when the rescuer's action conferred no practical benefit. In such circumstances liability without regard to success is justified-doctors and hospitals typically charge for their services, not results. A patient will owe fees regardless of whether a hoped-for result is obtained. A rescuee who obtains the same professional services under emergency conditions should not be allowed to evade hability because of the fortuitous circumstances. However, the Cotnam rule apphed ouly to professional rescuers.

In the cases of nonprofessional rescuers, there are no standard fees, since by definition these individuals are not in the business of performing rescues. As will be elaborated below, ${ }^{129}$ if the rescue is successful, a gain is produced which has a material value. ${ }^{130}$ Absent any payment from rescuee to rescuer, the entire gain accrues to the rescuee. Where the rescuer is a nonprofessional, who has suffered no physical or financial injury, and whose time commitment was minimal, no great imjustice results.

Where, however, the nonprofessional rescuer incurs significant costs or injuries during a successful rescue, the situation differs greatly. In ternns of restitutionary doctrine, the rescuee's enrichment is unjust

123. Id.

124. See generally supra Part I, Section $C$.

125. See infra text accompanying notes $134-40$.

126. See Dawson, supra note 1 , at $1083-85,1119,1129$.

127. See R. Poweil, The Law of Agency 416 (2d ed. 1969); M. Radin, Handbook of ROMAN LAW 301-02 (1927); see also R. GOFF \& G. JONES, supra note 15, at 5.

128. See supra notes $\mathbf{7 4 - 7 8}$ and accompanying text.

129. See infra Part III.

130. See supra text accompanying note 51 . 
because it was made possible only through the rescuer's loss. ${ }^{131}$ The cause of action envisioned by this Comment is grounded in basic restitutionary doctrine, ${ }^{132}$ and requires both a successful rescue and rescuer contribution. If the rescue attempt is unsuccessful, then the rescuee has not been enriched. ${ }^{133}$ If there is a successful rescue but the rescuer's efforts did not contribute to it, then rescuee's enrichment is not at rescuer's expense, and consequently is not unjust. The key concept, therefore, is that if a rescuee has been enriched, and, if rescuer has suffered a loss, only then has rescuee been enriched at rescuer's expense.

In cases mvolving successful rescues, the proposed reforin would operate similarly to negotiorum gestio. An illustration of a case, where the proposed reform would reach the same result as negotiorum gestio, a result impossible under current restitutionary doctrine, is provided by a famous German case ${ }^{134}$ that Professor Dawson discusses. ${ }^{135}$ In that case, a husband and wife were passengers im a car that went off the road and into a stream. All three occupants, the couple and the car's driver, escaped from the car and surfaced. The husband and the driver successfully swam to shore. The wife, however, could not swim, and cried loudly for help. Two workers on the bank heard her cries; one swam to the woman's aid. The worker held the struggling woman above the surface long enough for the car's driver to arrive and successfully pull the woman to safety. Unfortunately, the worker then drowned. ${ }^{136}$

The worker's widow and children brought an action against the couple $^{137}$ to recover for their loss of support. The action was upheld by the trial court, and two levels of appellate courts. The rescuer's wife received an annuity, as did each child. The result, however, has been criticized on the grounds of statutory construction, ${ }^{138}$ case interpretation, ${ }^{139}$ and policy. ${ }^{140}$

131. But see Dawson, supra note 1, at $\mathbf{1 1 2 5}$ ("Surely for many acts of neighborly help, though inconvenience and risk may be involved, one must be prepared to say that reimbursement by the person in peril is neither needed nor desired."); Dawson, supra note 90, at 88 ("My own conclusion ... is that private law remedies are misapplied when they create liability without fautt in the person whose life or liealth is saved.").

132. See REstatement of Restitution $\& 1$ (1937); REstatement (SECOND) OF RESTITUTION $\S 1$ (Tent. Draft No. 1, 1983).

133. For arguments that a rescuee is sufficiently benefited by unsuccessful rescue attempts to be liable to a rescuer for restitution, see Honoré, supra note 3, at 236 and Comment, supra note 43, at 619.

134. Judgement of May 7, 1941, Ger., 167 ReichSGericht IN ZivilSACHEN [RGZ] 83.

135. See Dawson, supra note 1, at 1108-11; Dawson, supra note 90, at 73-77.

136. Dawson, supra note 1, at 1108-09; Dawson, supra note 90, at 73-77.

137. Professor Dawson notes "there appeared nowhere in the case a finding that . . the driver of the car ... had been negligent, and the effects of his possible liability were not considered. Dawson, supra note 90, at 75.

138. See Dawson, supra note 1, at 1109-11; Dawson, supra note 90, at 75-77.

139. See Dawson, supra note 1, at 1109-11; Dawson, supra note 90, at 75-77.

140. See Dawson, supra note 1, at 1124-29; Dawson, supra note 90, at 83-89; Rudzinski, The 
Professor Dawson strongly condemns the case, claiming that the rule it established has produced "indefensible injustice and gross distortion of gestio doctrines." 141 This Comment disputes the weight of Professor Dawson's policy objection. ${ }^{142}$ As outlined above, ${ }^{143}$ a rescuee is enriclied by a successful rescue attempt. If the rescuer has incurred significant costs in effecting the rescue, then rescuee is enriclied at rescuer's expense. This enrichment is unjust unless rescuee assumes a fair sliare of the costs. Under the proposed reform, if the rescuer's recovery is carefully tailored according to, among other things, the rescuee's financial condition, no injustice to the rescuee results from allowing rescuer's claim. ${ }^{144}$

In surn, civil law, incorporating the doctrine of negotiorum gestio, allows results impossible under current interpretations of common law restitutionary primciples. ${ }^{145}$ Contrary to the common law insistence on values of individualism and autonomy, the civil law attitude "is that of encouraging a inan to act in an altruistic fashion in aiding anotler. No deprecating remarks are inade about the volunteer or the interineddler, and there is no refusal to grant him relief." 146 Since allowing sucl legal rewards is consistent witl both our moral instincts and the social policies underlying our basic restitutionary doctrines, justice under the common law would be served by looking to the civil law practice in this area.

\section{B. Maritime Law: Salvage}

Like civil law, Inaritime law is a fully developed legal system that offers rewards and inducements to prompt behavior thought to be socially useful. ${ }^{147}$ The contrast between maritime law and common law practice is all the more stark because the same British and American courts that rendered the common law restitutionary decisions criticized in Part I, also dispensed inaritime salvage awards witlout hesitation. ${ }^{148}$

Duty to Rescue: A Comparative Analysis, in The Good SAMARITAN AND THE LAw 91, 117 (J. Ratcliffe ed. 1966).

141. Dawson, supra note 1 , at 1129.

142. See supra text accompanying note 1 . This Comment is primarily concerned with refuting Professor Dawson's policy objection to this case. As to Dawson's objection that gestio doctrines were misapplied in this case, Professor Honore explicitly approves the use of gestio theory to uphold the type of recovery allowed in the case. See Honore, supra note 3, at 236. Whatever the merit of Dawson's legal objection, the case at issue is valuable because it illustrates that gestio doctrines can be construed to reach results impossible under current restitutionary doctrine.

143. See supra text accompanying notes 130-33.

144. See infra Part III, Section $C$.

145. But see Marasinghe, supra note 117.

146. Wade, supra note 17 , at 1210 .

147. See The Blackwall, 77 U.S. (10 Wall.) 1, 14 (1869).

148. See Wade, supra note 17 , at 1208-11. 
The leading American treatise on maritime law explains the nature of salvage as follows:

On land the person who rushes to save another's property from danger is an officious intermeddler, the volunteer whom even equity will not aid. He has no right to a reward, although he may incur liability if he damages the property in the course of saving it. The person who saves life on land is similarly treated, except that he may count on a paragraph in the court's opinion paying tribute to his good character.

At sea the person who saves property receives a reward which is generously computed in light of "the fundamental public policy at the basis of awards of salvage-the encouragement of seamen to tender prompt service in future einergencies." The reward, it has often been said, is not a mere recompense for work and labor done, not a quantum meruit. "Public policy ... encourages the hardy and adventurous mariner to engage in these laborious and sometimes dangerous enterprises and with a view to withdraw from him every temptation to embezzleinent and dishonesty allows him, in case he is successful, a liberal coinpensation." Whether the fundamental purpose is to encourage heroism or to discourage embezzlement, the fortunate participants in a salvage operation where large values are at stake may count on a handsome reward. ${ }^{149}$

As this passage suggests, a salvage award goes beyond the mere measure of the salvor's restitution interest. Because it depends on the nature and value of the property saved as well as other factors, the award may well exceed the fair market value of the salvor's services. ${ }^{150}$

There are three prerequisites to eligibility for a salvage award. First, there must have been a danger at sea "froin which the ship or other property could not liave been rescued without the salvor's assistance."151 Second, "[t]lie salvor's act must be voluntary-that is, he must be under no official or legal duty to render the assistance." 152 Third, "[t]he act must be successful in saving, or in helping to save, at least a part of the property at risk." 153 Once a salvor lias made this preliminary showing, his award will be determined by reference to an established list of factors.

The classic American formulation of the factors used in determining a salvage award is as follows:

(1) The labor expended by the salvors in rendering the salvage service.

(2) The promptitude, skill and energy displayed in rendering the service and saving the property. (3) The value of the property employed by the

149. G. GiLmore \& C. BLACK, The Law of Admiralty § 8-1, at 532 (2d ed. 1975) (footnotes omitted). The two leading treatises devoted exclusively to salvage are K. MCGUFFIE, KENNEDY's Civil Salvage (4th ed. 1958) (on English law); M. Norris, The Law of Salvage (1958) (on American law).

150. See G. Gilmore \& C. BLACK, supra note $149, \S 8-9$, at 562.

151. Id. § 8-2, at 534-35.

152. $I d$.

153. Id. 
salvors in rendering the service, and the danger to which such property was exposed. (4) The risk incurred by the salvors in securing the property from the impending peril. (5) The value of the property saved. (6) The degree of danger from which the property was rescued. ${ }^{154}$

In considering the worth of the salvor's efforts, the trial judge evaluates "what might be called the moral aspects of the salvage service."155 This aspect of the salvage award determination is peculiarly within the discretion of the trial judge. "[I]t goes without saying that in passing on the inoral worth of a salvage service the trial judge is operating on plastic inaterial which he can shape to suit his own fancy."156

The major problein in using the law of salvage to buttress an arguinent in support of a land-based restitutionary remedy for life rescuers is that traditionally awards were granted only for the salvage of property, and not for the salvage of life. ${ }^{157}$ This policy has been altered by statute in both England ${ }^{158}$ and the United States, ${ }^{159}$ largely because "there was a natural temptation to save property first and look around for survivors later."160 Yet a vestige of the original rule denying an award for the salvage of life remains, at least as a statement of black letter law, im that "pure" life salvage, unaccompanied by property salvage, still goes unrewarded. ${ }^{161}$

The rationale for the rule denymg an award for life salvage has to do with the nature of a salvage proceeding. The action brought by a salvor is $\mathrm{m}$ rem against the ship or any other property rescued. ${ }^{162}$ Obviously, a salvor conld have no hen on a rescuee, so a claim for life rescue was entirely outside the scope of a traditional salvage proceeding. ${ }^{163}$

154. The Blackwall, 77 U.S. (10 Wall.) 1, 14 (1869). A similar but more specific list is provided in K. MCGUFFIE, supra note 149, at 174.

155. G. GILMORE \& C. BLACK, supra note 149, § 8-9, at 562. But see Landes \& Posner, supra note 80 , at $103 \mathrm{n.44}$ (chiding Gilmore and Black for descibing "the obviously economic aspects of the salvage-award determination . . . as the 'moral aspects' of the award").

156. G. GILMORE \& C. BLACK, supra note $149, \S 8-9$, at 562.

157. Id. $\S 8-1$, at 532 ("Historically, the saving of hife was regarded as fulfilling a moral duty but not as entitlimg the salvor to a reward.").

158. See Merchant Shipping Act, 1894, 57 \& 58 Vict., ch. 60, §§ 544-545; see also K. MCGUFFE, supra note 149 , at $398-400$.

159. Act of Aug. 1, 1912, ch. 268, §3, 37 Stat. 242 (1912) (codified at 46 U.S.C. $\S 729$ (1982)).

160. G. Gilmore \& C. BLACK, supra note 149, § 8-1, at 532.

161. Id.

162. See S. STolJAR, supra note 13 , at 172 . An additional reason might be that, contrary to basic tort principles on land, there is a general duty to rescue life at sea. See International Convention for the Safety of Life at Sea, June 10, 1948, ch.5, reg. 10, 3 U.S.T. 3450, 3654, T.I.A.S. No. 2495, 164 U.N.T.S. 113, 332-34. The existence of this duty would, of course, negate one of the three eligibility prerequisites to a salvage award. See supra text aecompanying note 152 .

163. See Wade, supra note 17, at $1208 \mathrm{n} .142$ ("[t] normally been in the forn of a lien on the property has meant that the courts have proved less ready in giving reinedy in cases involving the saving of life."); see also Jarett, The Life Salvor Problem in Admiralty, 63 YALE L.J. 779 (1954). 
The statutes referred to above ${ }^{164}$ do not entirely change the result. They merely allow salvors who have rescued life to claim a portion of the fund created by other salvors who rescued property as part of the same rescue operation. ${ }^{165}$ If no salvor rescued property, or if there was no property to rescue, no fund is created and theoretically there can be no recovery of a salvage award. ${ }^{166}$ Enghish law has mitigated this hardship; its life salvage statute grants an independent right to claim a life salvage award which may be satisfied out of a Mercantile Marine Fund (as provided by Parhament) if no property is preserved. ${ }^{167}$

The American black letter rule denying an award for "pure" life salvors has been much criticized ${ }^{168}$ and a recent Second Circuit decision calls its continued authority into question. In Peninsular \& Oriental Steam Navigation Co. v. Overseas Oil Carriers, ${ }^{169}$ plaintiff's ship incurred significant additional fuel costs detouring froin its scheduled route to pick up an ailing seaman froin defendant's ship that lacked the necessary medical facilities. Defendant voluntarily paid plaintiff's costs in providing medical treatinent to the seaman, but refused to reimburse plaintiff for its increased fuel costs. The trial court found that plaintiff could not recover these expenses because (1) plaintiff's acts, however commendable, did not confer a legally cognizable benefit on it, and (2) plaintiff's acts constituted "pure life salvage" for which there could be no recovery. ${ }^{170}$

Brusquely turning aside both these objections, the Second Circuit, in an opinion by Chief Judge Kaufman, apphed land-based restitutionary rules to circumvent the maritine rule agamst "pure life salvage." The Peninsular court reasoned that in providing inedical assistance to the stricken seaman, plaintiff had performed defendant's duty to a third person. ${ }^{171}$ Such performance, "if rendered by one qualified to provide such services with intent to charge for them ... where the services are imme-

164. See supra notes $158 \& 159$.

165. See G. GiLmore \& C. BLACK, supra note 149 , § 8-12, at 570-74. Gilmore and Black claim that the American statute is of relative unimportance because usually a salvor will have rescued both life and property. They also observe, however, that "[i]f the few life salvage awards which have been made are enough to support a generalization, it can be said that it is still far more profitable to save property than to save hives." Id. at 573.

166. Id at 573 .

167. See Merchant Shipping Act, 1894, 57 \& 58 Vict., ch. 60, §§ 544-545; see also Note, Restitution for Life Salvage at Sea in the Wake of Peninsular \& Oriental Steam Navigation Co. v. Overseas Oil Carriers, Inc., 30 Hastings L.J. 227, 235 n.50, 236 n.55 (1978).

168. See Jarett, supra note 163; see also Friedell, Compensation and Reward for Saving Life at Sea, 77 Mich. L. REv. 1218 (1979); Note, supra note 167; Comment, Compensation for Life Salvage at Sea 2 Hastings L.J. 53 (1951).

169. 553 F.2d 830 (2d Cir.), cert. denied, 434 U.S. 859 (1977). The significance of this casc is analyzed in Note, supra note 167.

170. Id. at 835 .

171. Id. at 834 . 
diately necessary to prevent injury or suffering," is grounds for recovery in quasi-contract. ${ }^{172}$ The court summarily rejected defendant's contention that the principles of quasi-contract were inapplicable to proceedings in admiralty. ${ }^{173}$ Furthernore, in a footnote, the Penisular court found "[i]t is not necessary, in cases of this character, that the 'benefit" conferred be of a inonetary nature."174 The most notable aspect of the Peninsular decision is that the court exphicitly weighed considerations of public policy and morality, and refused to defer to the outmoded "pure life salvage" doctrine. ${ }^{175}$ The court pointed to the logical flaws of the "pure life salvage" rule, stating that "[ $t]$ he irrationality of providing rewards for property salvage but not requiring payment for rescuing lives has been under attack for many years."176

In suin, the law of salvage, like the doctrine of negotiorum gestio, provides a marked contrast to the common law of restitution in its encourageinent of "the rendering of aid to another without his prior request."177 Professor Hope writes that "salvage represents in our law the purest strain of quasi-contract principles," and he urges the large scale incorporation of salvage law into restitutionary doctrine. ${ }^{178}$ Dean Wade asserts that einergency rescues on land and sea are mdistinguishable: "The only real difference is that custom has now developed so that the salvor at sea always expects compensation and there is no presumption of gratuity."179 In these ways, the law of salvage provides a inodel for the progress and development of common law restitutionary doctrine.

172. Id.

173. Id. at 835 . The court cited modern developinents in the law that supported its holding: Although it is true that the fortuitousness of jurisdiction in eighteenth century English courts long left the application of restitutionary principles to admiralty in doubt, today the law is clear that quasi-contractual claims may be considered by the federal courts in admiralty if they arise out of maritime contracts ... or other inherently maritine transactions ....

Id. (citations and footnote omitted).

174. Id. at 835 n. 4 .

175. Id. at 836 (court refuses "to defend ... to this hoary, and almost universally condemned, rule of the sea").

176. Id. at 836 n.6 (citing Jarett, supra note 163 ).

177. Wade, supra note 17 , at 1211 .

178. Hope, supra note 13 , at 36 (footnote omitted).

179. Wade, supra note 17, at 1210 (emphasis added); see also Hunter, supra note 15 , at 7 . But see $\mathrm{R}$. GOFF \& G. JONES, supra note 15 , at 271 (objecting to a land salvage remedy wherein a nonprofessional rescuer would receive remuneration for his services; these authors recoininend a land salvage remedy wherein all rescuers would receive reimbursement for their expenses whether or not the rescue was successful, see supra note 105 and accoinpanying text); Landes \& Posner, supra note 80 , at $113,118-19$ (distinction between land and sea rescue doctrine justified by notions of cconomic efficiency). 
III

\section{The Proposed Reform}

Part I outlined the common law hostility to unsolicited rescues, and analyzed three exceptions that it argued could not be limited to their current narrow application. Part II outlined two legal systems that offer significant encouragement to unsolicited rescue. One of these systems, maritime law, is notewortliy because it is admimistered in common law countries largely by the same judiciary that adjudicates restitutionary claims. Part III now proposes a cause of action for successful unsolicited rescuers who suffer injury during the rescue. This cause of action, grounded in basic concepts of restitution, ${ }^{180}$ will synthesize desirable features of civil and maritime law with the existing common law exceptions discussed in Part I.

The proposed reform ${ }^{181}$ would allow a clami by a nonneghigent, ${ }^{182}$ nonprofessional individual who performs or contributes to an unsolicited rescue of another im imminent peril to life or health. Nonprofessional rescuers would be able to recover out-of-pocket expenses directly incurred in the rescue, but not compensation for services rendered, unless they can establish that the rescue required significantly more time or effort than reasonably could have been expected at the outset of the rescue. Professional rescuers, however, would recover their standard fees for services rendered whether or not the rescue is successful. But, professionals would not recover their expenses, unless they can establish that their usual fees do not imclude a component covering the risk of such expenses. In all cases, the claim would be against the individual rescued.

The rationales for each of the proposed reform's major components-presumption of nongratuity, requirement of success, and measure of recovery-are discussed below.

\section{A. Presumption of Non-Gratuity}

As stated above, the single mechanism of current restitutionary doc-

180. See supra note 5 and accompanying text.

181. A concrete example of a situation where the proposed reform would allow a rescuer a rccovery that current restitutionary doctrine clearly would not, is provided by the German case discussed in Part II, Section A. See supra text accompanying notes 134-40.

For two well-drafted alternate reform proposals in this area, see Miller \& Zimmerman, The Good Samaritan Act of 1966: A Proposal, in The Good SAMARITAN AND THE LAW 279 (J. Ratcliffe ed. 1966); Rudolph, supra note 40.

182. In a comparative negligence jurisdiction, the proposed reform would work as follows. A rescuer's negligence would not necessarily be a complete bar, but would instead reduce any recovery. Restitutionary theory justifies such a result because a rescuee is not unjustly enriched to the extent the rescuer negligently caused his own injuries. On the other hand, to the extent the rescuer's negligence was only an aggravating factor, under a comparative negligence system the rescuer's recovery should be reduced but not eliminated. Other components of the proposed reform would remain unchanged in comparative negligence jurisdictions. 
trine most likely to bar a nonprofessional rescuer's claims is the presumption of gratuity. ${ }^{183}$ This presumption, as currently applied, is a dubious assessment of human nature ${ }^{184}$ and is contrary to considerations of fairness and social policy. ${ }^{185}$

To cure these faults, the proposed reform would reverse the existing presumption to a presumption that all rescuers intend to charge. The new presumption would be rebuttable and the rescuee would bear the burden of proof that the rescuer did not intend to charge. ${ }^{186}$ For example, the rescuee could introduce post-rescue statements by the rescuer that rebut the intent to charge. On the other hand, to prevent imjustice to the rescuee, the proposed presumption would be narrower in scope than the one currently in force because neither the nonprofessional or the professional rescuer will be presumed to intend to charge for both services and expenses.

In the first case, a nonprofessional rescuer will be presumed not to have intended to charge for this service rendered. This provision, which is also a feature of negotiorum gestio doctrine, ${ }^{187}$ accords with simple justice and the intuition that people should be willing to give of themselves gratuitously. If a rescuer's total loss from the rescue effort is only a few hours of time, it is difficult to conclude that the rescuee has been unjustly enriched at the rescuer's expense. Of course, the rescuer can overcome this provision by showing that he reasonably believed that, for example, the rescue would take two hours, when it in fact took two days. Current restitutionary doctrine already seems to recognize this point, at least in part. ${ }^{188}$ On the other hand, the nonprofessional cannot be presumed to have intended to donate all out-of-pocket expenses incurred. ${ }^{189}$

In the second case, as under current law, ${ }^{190}$ the presumption will be

183. See supra notes $20-24 \& 91-115$ and accompanying text.

184. See supra notes $94 \& 104-05$ and accompanying text.

185. See supra notes 104-05 and accompanying text. The theoretical illogic of the current presumption of gratuity, and its function as a mechanism to deny otherwise supportable claims for restitution, is revealed by the way it is glossed over when there has been post-rescue ratification. See supra notes 56, 65-73 and accompanying text. If, as the $W e b b$ rule allows, a rescuer's intent to charge can be established by his aceeptance of rescuee's payment or promise to pay after the fact, then similarly, a rescuer should be able to establish his intent to charge by merely making a claim for restitution afterwards.

186. Furthermore, since the proposed presumption is rebuttable, the rescuee would have a significantly lower evidentiary burden than the rescuer now has to prove his intent to charge. Some commentators construe current case law as establishing an irrebuttable presumption of gratuity. See, e.g., Landes \& Posner, supra note 80, at 109 n.60.

187. See supra note 126 and accompanying text.

188. See Restatement (SECOND) OF Restitution $\$ 3$ comment c (Tent. Draft No. 1, 1983) ("The precept [that the virtue of performing emergency services is its own reward] is relaxed somewhat when ... [the emergency] entails prolonged and costly effort.").

189. See supra notes $90-105$ and accompanying text.

190. See supra notes $74-79$ and accompanying text. 
that professional rescuers intends to charge for their services, but not specifically for their expenses. The underlying rationale is that in inost professions expenses are calculated into fee schedules. It would be inanifestly unjust to allow a professional rescuer to recover both the normal fee for services, including an expense surcharge, and a fee for actual expenses. Suppose a inountaineering guide, while doing some solo weekend climbing, discovers and rescues a stranded hiker. The guide, whose norinal business includes rescuing individuals from dangerous precipices, and who sets his fees to adequately cover the risks and equipment involved, should only recover his nornal fee for inountaineermg, rather than collecting an additional award for expenses. To the extent that a professional rescuer can establish that his and the profession's fee schedules do not incorporate such a risk premium, or that he follows a practice in the profession of billing for expenses separately, a professional rescuer would recover actual expenses in addition to norinal fees. ${ }^{191}$

\section{B. Requirement of Success}

Perhaps the inost probleinatic aspect of the proposed reforn is that it requires that a rescue be successful. Considerations of morality and public policy do not vary with the fortuitous outcome of nonnegligent rescue efforts, and the nonnegligent rescuer who is injured while attempting a rescue should be coinpensated. Yet just because the rescuer deserves compensation does not mean that the rescuee should provide it. ${ }^{192}$ Since the proposed reform is grounded in restitutionary doctrine, it would hold that a rescuer is only entitled to a remedy against a rescuee if the rescue has conferred a benefit. ${ }^{193}$ If the rescue is unsuccessful, or if the rescuer's acts did not contribute to the rescue, then the rescuee has not been unjustly enriched at the rescuer's expense.

In having a rescuer's recovery depend on a contribution to a successful rescue, the proposed reforin looks to salvage rather than negotiorum gestio as its model. While the fundamental concept of negotiorum gestio is reimbursement for justifiable "management of another's affairs," 194 the fundamental concept of the proposed reform is unjust

191. See supra notes $56,65-73$ and accompanying text.

192. This Comment's author is sympathetic to the establishment of a government fund. The British Parhament has established such a fund for life salvage at sea. See supra note 167 and accompanying text. Dean Wade also points out that "[s]everal jurisdictions have enacted 'Good Samaritan indemnification legislation,' providing for governmental reimbursement to a private citizen injured or damaged in attempting to prevent the commission of a crime against the personal property of another." Wade, supra note 17, at 1188 n.26 (citing laws in California, Delaware, New York City, and New Zealand); see Honoré, supra note 3, at 236-37. The optimum government fund would compensate not only unsuccessful nonnegligent rescuers, but also successful nonnegligent rescuers who happened to have saved indigent rescuees.

193. See supra note 5 and accompanying text.

194. See supra note 118 and accompanying text. 
enrichment. ${ }^{195}$ Thus, while an unsuccessful rescuer may have justifiably "managed the affairs" of the rescuee, such a rescuer has not conferred a benefit on the rescuee that unjustly enriches the rescuee at the rescuer's expense.

Some commentators have disputed this point, claiming that a rescuee is benefited by any and all nonnegligent rescue attempts. ${ }^{196}$ One commentator rehes on negotiorum gestio concepts of innphed agency. ${ }^{197}$ Other commentators nake arguments like the following: "Success in the rescue effort is not a condition of recovery presumably for the reason that the defendant would, if rational, have wished that the attempt be made and would have authorized the expenditure imvolved."198

This reasoning confuses implied-in-fact and innplied-in-law contracts. An implied-in-fact contract is a true contract, but the parties have manifested their agreennent by their conduct rather than by their express words. ${ }^{199}$ On the other hand, "[a] contract innplied in law is not a contract at all but an obligation innosed by law to do justice even though it is clear that no promise was ever made or intended."200 An inplied-infact contract cannot be formed in the usual rescue situation because of the absence of even a tacit meeting of the mimds. In any event, in a rescue situation where an inplied-m-fact contract is fonnd to exist, a remedy will he without recourse to a restitution model at all.

The creation of an implied-in-law contract depends on a weighing of social policy-whether it is just under the circumstances for the law to innose an obligation on an individual without his consent. What the parties might have agreed to had they the chance does not necessarily determine whether the law will impose a similar obligation. Under the unjust-enrichment analysis used for implied-m-law contracts, the rescuer's acts inust have conferred a benefit upon the rescuee for the rescuee to be obligated to the rescuer. ${ }^{201}$

Unsuccessful rescue efforts only benefit the rescuee if viewed from an ex ante or "before-the-outcoine" perspective. Use of the ex ante perspective operates under existing doctrime to bar a nonprofessional rescuer's recovery when it is used in determining whether a rescuer had an intent to charge before atteinpting the rescue. ${ }^{202}$ Yet adoption of this perspective together with the proposed reform's reversed presumption of

195. See supra text accompanying notes 129-33.

196. See, e.g., Honoré, supra note 3, at 236; McCamus, supra note 15, at 311-12; Rudolph, supra note 40, at 261-63, 265-66; Comment, supra note 43, at 618-19.

197. See Honoré, supra note 3, at 236; see also supra notes $117-23$ and accompanying text.

198. McCamus, supra note 15, at 311-12; see also Rudolph, supra note 40, at 261-63, 265-66.

199. See J. Calamari \& J. Perillo, supra note 50, § 1-12, at 19.

200. Id. (footnote omitted); see also Hope, supra note 13 , at 31 .

201. See supra note 5 and accompanying text.

202. See supra text accompanying notes $102-05$. 
intent to charge would render the rescuee unjustly obligated because of a "benefit" that ultimately had no value. ${ }^{203}$ In the interests of fairness and consistency, use of the ex ante perspective inust be rejected both when determining whether rescuer had an intent to charge and when determining whether rescuer's acts conferred a benefit on the rescuee.

\section{Measurement of Recovery}

Under the general rules of restitution, "[a] person who has been unjustly enriched at the expense of another is required to make restitution to the other."204 The basic remedial goal of restitution must be the restoration, as nearly as possible, of the positions the parties occupied before the event giving rise to the claim for restitution (i.e., the status quo ante). ${ }^{205}$ The proper ineasure of the remedy in the rescue setting, however, is not clear froin these general primciples.

The usual restitutionary ineasure of recovery is the value of the benefit conferred. In a rescue context, this benefit is the rescuee's contimued life or health. However, awarding the full value of the rescuee's life, as judicially determined, to the rescuer would be both problematic and excessive.

This valuation would be problematic because current restitutionary doctrine provides no valuation guidelines. Although it is often necessary to determine the value of a life $\mathrm{m}$ wrongful death cases arising in tort, for exainple, it is unlikely that the same inethodology would be appropriate in evaluating a restitution claim. This valuation would be excessive because the value of an individual's life is determined by many factors, including the individual's own accoinplishments. The rescuer cannot fairly claim an entitlenent to the rescuee's net worth by virtue of a successful rescue.

Thus, a surrogate ineasure of the benefit conferred is in order. The Restatement of Restitution explicitly acknowledges this point:

Actions for restitution have for their primary purpose taking from the defendant and restoring to the plaintiff something to which the plaintiff is entitled, or if this is not done, causing the defendant to pay the plaintiff an anount which will restore the plaintiff to the position in which he was before the defendant received the benefit. ${ }^{206}$

203. Under an ex ante perspective, the rescuee would not know whether an attempted rescue would be successful. A rational rescuee, then, would hope for as many nonnegligent rescuers as possible in order to maximize the possibility of successful rescue. Until the rescue is completed or the need for rescue passes, the rescuee's interests are served by each nonnegligent rescuer who attempts a rescue. Therefore, under the ex ante perspective, the rescuee would benefit froin all nonnegligent rescue atteinpts and would be potentially liable for each rescuer's expenses.

204. RESTATEMENT OF RESTITUTION $§ 1$ (1937).

205. Id. at 595-96 (Topic 2 Introductory Note).

206. Id. 
In the rescue context, as argued above, the rescuer should not be entitled to the full value of the rescuee's life. It would be more proper to measure the rescuee's benefit conferred by the detriment suffered by the rescuer. The rescuee, after all, hardly has a just complaint. ${ }^{207}$

The proposed reform would award the rescuer the value of the detriment suffered, adjusted by certain equitable factors, to ensure that the surrogate measure does not exceed the benefit realized by the rescuee. Thus, the proposed measure of recovery would be inore favorable to a rescuee's interests than a inechanical application of the standard restitutionary ineasure. Though these general principles are helpful, specific rules are needed. The Restatement of Restitution provision most relevant to a nonneghigent rescue situation reads as follows:

(1) Where a person is entitled to restitution from another because the other, without tortious conduct, has received a benefit, the measure of recovery for the benefit thus received is the value of what was received, limited, if the recipient was not at fault or was no more at fault than the claimant, to its value im advancing the purposes of the recipient, except as limited by the statement in Subsection (2).

(2) Where a transaction is rescinded solely because of a mistake as to price, the recipient's duty of restitution is to pay not less than he expected to pay nor more than the claimant expected to receive. ${ }^{208}$

Unfortunately, even this provision does not concretely answer the problein of measuring restitution in a life rescue situation.

The difficulty with trying to apply the above general principles to a rescue situation is that rescission is impossible, the rescuer's loss may be greater than the rescuee's gain, and in any case, the rescuee's gain cannot be objectively measured. This difficulty arises whenever restitution is sought for unsohicited services. ${ }^{209}$ Professor Jones poses the problem as follows:

The receipt of money is uncontrovertibly a benefit. So too, generally, is the delivery of goods. But the receipt of services may not benefit the recipient; for services, once rendered, cannot be restored. The recipient may not have wanted the services or at least not wanted them if lie knew that he had to pay for them. In the words of a nineteentli-century Englisli judge: "a person cleans another's shoes: what can the other do but put them on?"210

In rescue situations, modern courts have had hittle problem conclud-

207. See infra text accompanying note 225.

208. RESTATEMENT OF RESTITUTION $\S 155$ (1937).

209. Cf. Birks, Restitution for Services, 27 CuRrent Legal Probs. 13 (1974). See Jones, supra note 26.

210. G. Jones, Anglo-American Trends in Restitution, Lecture at the University of Amsterdam in Commemoration of the graduation of Marcel Henri Bregstein to the degree of Doctor of Laws 5 (Dec. 16, 1977) (available in Harvard Law School Library) (quoting Taylor v. Laird, 156 Eng. Rep. 1203 (1856). 
ing that the rescuee wanted the services, or even, in principle, determining that the rescuer deserved some recoinpense for his efforts. ${ }^{211}$ It is the objective determination of the benefit conferred that poses the problem. Dean Wade observes:

A reasonably certain measurement of the enrichment is . . . needed. Thus, where the plaintiff saves the defendant's he, it certainly would not be thought that the total value of the defendant's life expectancy is the measure of the enrichment. There is, mdeed, no accurate basis for measuring the benefit, and this may well be an important reason why courts have been slow to grant recovery im this situation. ${ }^{212}$

There are several possible ways to solve this conundrum. First, there is the approach actually taken im the early cases-commending the rescuer for his deeds, but holding that virtue is its own reward. ${ }^{213}$ This result is still supported by soine reputable modern commentators. ${ }^{214}$ This Comment, however, rejects such an approach as contrary to the

211. See generally 2 G. PALMER, supra note $6, \S 10.4$, at 374-83.

212. Wade, supra note 17 , at 1187 (footnote omitted).

213. See supra notes $20-23$ and accompanying text. But see note 96 and accompanying text.

Perhaps the attitude that "virtue is its own reward" appears most emphatically as a rule of legal decision in Nicholson v. Chapman, 126 Eng. Rep. 536 (1793). The court there rejected the plaintiff's restitntionary claim for services rendered in protectimg defendant's property by stating:

This is a good office, and meritorious, at least in the moral sense of the word, and certainly intitles [sic] the party to some reasonable recompence from the bounty, if not from the justice of the owner ... perhaps it is better for the public that these voluntary acts of benevolence from one man to another, which are charities and moral duties, but not legal duties, should depend altogether for their reward upon the moral duty of gratitude.

Id. at 539. This appears to be the sort of decision Honore was contemplating when he wrotc:

One cannot but sense in some judicial utterances a certain pride in the irrational, incalculable depravity of the law, as if this demonstrated its status as an esoteric science, inaccessible to the common run of mankind. As the Russians said of Stalin: a monster, but ours.

Honoré, supra note 3, at 241. 12.

214. See, e.g., Dawson, supra note 90, at 83-89; see also Landes \& Posner, supra note 80, at 109.

Landes and Posner's views on this subject are predictable, for they both advocate economic analysis of law. See generally R. Posner, Economic ANalysis of LAw (2d ed. 1977). Professor Dawson's views are more surprising, since he generally advocates liberalizing traditional restitntionary rules. At root, though, his views are really no different than those expressed in Glenn v. Savage, 14 Or. 567, 13 P. 442 (1887). See supra notes 22-23 and accompanying text. His views on life salvage, however, are even more startling when contrasted with his more liberal views on property salvage. Compare Dawson, supra note 1, at 1128-29, with Dawson, supra note 90, at 88-89.

Professor Dawson states:

Remedies and doctrines of private law are ill adapted to measuring the value of human life. I sec no compelling reason why they should be used to transfer the risks of our life together in a perilous world or to limit the price we all must pay for the privilege of being human beings.

Dawson, supra note 90 , at 89.

Nevertheless, this Comment argues that no matter how ill-adapted private law remedies may be, failure to use them results in much greater injustice than using them ever could. Under Professor Dawson's scheme, communal risks are not shared at all. Dawson would impose all the costs of rescue on those who, because they choose to act in another's interest, most deserve our commendation. 
fundamental restitutionary principle of curing unjust enrichment. ${ }^{215}$

Second, an intermediate position is possible. One can allow a rescuer some form of recovery, but also greatly restrict a rescuee's liability without fault. Judge Goff and Professor Jones's view, that rescuers ought to recover their "expenses" but not tlieir "losses," category. ${ }^{217}$ In this case, however, a partial recovery entails only partial justice. Goff and Jones's theory would give only trivial compensation for the most needy rescuers. No principled distimction slionld be made between outlays of cash and outlays of physical resources. In fact, the latter should be more highly valued.

Third, there is the approach which Dawson claims has produced "indefensible injustice."218 This approach involves a tort-like measure of the rescuer's injuries to assess the rescuee's enrichment. This approach has been used not only in the civil law cases Dawson criticizes, ${ }^{219}$ but also in some American nonrescue cases. ${ }^{220}$ Nonetlieless, this Comment endorses this alternative, with some caveats.

The rescuer's recovery should be determined by first consulting a list of factors similar to that used im determining a maritime salvage award. $^{221}$ But since it would be extremely difficult to place a value on the rescuee's life, the emphasis would be on the quality of the rescuer's efforts and the extent of the rescuer's injuries. To insure that the rescuee's obhigation to the rescuer does not impose an undue hardship on the rescuee's resources, a court would be able to scale down the award. ${ }^{222}$

215. See supra Part III, Section $B$; see also Wade, supra note 17 , at 1183.

216. Goff and Jones have defined "expenses" to exclude the costs of medical treatment and lost earnings, which they categorize as "losses." See supra note 105. Goff and Jones's definition of "expenses" seems unique. This Comment uses "expenses" in its generally understood meaning by including both medical costs and lost earnings as properly recoverable expense items. See REsTATEMENT (SECOND) OF TORTS $§ 924$ (1979).

217. See R. GoFF \& G. JoNEs, supra note 15, at 272-73; see also supra note 105.

218. Dawson, supra note 1 , at 1129 . See supra notes $134-41$ and accompanying text.

219. Dawson, supra note 1 , at 1110-14, 1121-24, 1128-29.

220. See, e.g., Campbell v. Tennessee Valley Auth., 421 F.2d 293 (5th Cir. 1969); Williams v. Umited States, 127 F. Supp. 617 (Ct. Cl. 1955). In Campbell, a vendor provided microfilm rolls to a government library pursuant to an unenforceable contract. The court measured the benefit to the government by the detriment to the vendor, which the court found was equal to the contract price. Campbell, 421 F.2d at 297. In Williams, the court found on facts similar to Campbell that the government was liable to pay contractors their fees despite the unenforceability of a contract. Williams, 127 F. Supp. at 623; see also 3 G. PALMER, supra note $6, \S 14.15$, at $216-17$ \& $\S 15.11$, at 448-49. But see Recent Developments-Contracts: Party Held Liable in Quasi-Contract for the Value of Services Rendered Rather than Benefit Received, 1970 DUKE L.J. 573 (criticism of Campbell analysis and holding).

221. See supra text accompanying note 154; see also Honoré, supra note 3, at 234 ("The relevant factors [for deciding whether a rescuer is entitled to recover] are easy enough to list: the gravity of the peril, the chances of successful intervention, the attitude of the victim, and the likelihood that another better-qualified rescuer will act.").

222. See Dawson, supra note 1, at 1116-18; Dawson, supra note 90, at 79-80, 86-87; Honoré, supra note 3 , at $233-34$. 
Also, if the rescuee can show that the harm the rescuer suffered (e.g., death) was totally disproportionate to the potential harm threatening the rescuee (e.g., a broken arm), the award could be scaled down even further. If the rescuer's intervention was not justified or was unreasonable, or if the rescuer was negligent, an absolute bar to recovery could be imposed. ${ }^{223}$

The proposed reform is an attempt to inake the practical results of current restitutionary doctrime conform with the theoretical ideals underlying them. Allowing a nonneghigent and successful rescuer a claim for out-of-pocket expenses against a nonnegligent rescuee, but tempering the claim in light of the rescuee's financial resources, will result in progress toward this goal. Dawson may claim that even in life rescue situations, "in the absence of some expressed consent[,] it seeins grossly unjust to cast all the hability on the rescued person."224 This objection pales, however, in contrast to Honorés observation: "The rescue[e] benefits froin being saved, and even if he is coinpelled to coinpensate the rescuer he will be, by and large, better off."225

\section{CONCLUSION}

The underlying preimise of this Comment has been that life rescue is an act worthy of society's encouragennent. Current law largely discourages rescue by erecting substantial barriers against recovery by a nonprofessional rescuer injured in a rescue atteinpt. The unsatisfactory state of current rescue law is evidenced by the major tort, contract, and restitution law exceptions that courts have created to reduce the harshness of the general rule of nonrecovery. None of the rationales underlying each exception can be limited in a primcipled fashion to their current narrow applications. Each exception logically supports the proposed reform, which allows a successful nonneghigent rescuer a recovery of expenses against his rescuee even if the rescuee limiself is nonnegligent.

The current general rule agamst such a recovery is all the inore reprehensible since viable models of systems that recoinpense rescuers are provided by civil and maritime law. Key civil and inaritine law concepts should be incorporated into the common law to ensure a rescuer's just compensation. Under the proposed inodel, fairness to the successful nouneghigent rescuer is achieved by requiring a rescuee unjustly enriched by the rescuer's actions to reinburse the rescuer for out-of-pocket expenses. Fairness to the rescuee, who may also be nonnegligent, is achieved by allowing a trial court to consider certain equitable factors.

223. If the proposed reform were employed in a comparative negligence jurisdiction, the rescuer's negligence might not be an absolute bar. See supra note 182.

224. Dawson, supra note 1 , at 1126.

225. Honoré, supra note 3, at 233. 
Most important among those factors is the rescuee's ability to pay, so that the rescuee's liability will not be excessive.

In the famous rescue case of Webb v. McGowin, ${ }^{226}$ Judge Samford's complete concurrence was as follows:

The questions involved in this case are not free from doubt, and perhaps the strict letter of the rule, as stated by the judges, though not always in accord, would bar a recovery by plaintiff, but following the principle announced by Chief Justice Marshall in Hoffman v. Porter, . . . where he says, "I do not think that law ought to be separated from justice, where it is at most doubtful," I concur in the conclusions reached by the court. ${ }^{227}$

This Comment acknowledges that imposing a possibly heavy liability upon a nonnegligent rescuee may well be thought onerous. But this objection lacks force, because the rescuee is undoubtedly better off as a result of the rescuer's efforts. The common law was justifiably wary of externally imposed private liabilities, but in the rescue situation, personal autonomy is outweighed by other compelling societal values. Justice requires that a rescuee who has enjoyed the benefits of a rescuer's efforts bear the costs of that benefit to the extent the rescuee is financially able.

Ross A. Albert*

226. 27 Ala. App. 82, 168 So. 196 (1935), cert. denied, 232 Ala. 374, 168 So. 199 (1936). See also supra Part I, Section $B$.

227. Id. at 86, 168 So. at 199 (Samford, J., concurring) (citation omitted).

* A.B. 1982, Harvard University; third-year student, Boalt Hall School of Law, University of California, Berkeley. 
